\title{
Greenhouse gas measurements from a UK network of tall towers: technical description and first results
}

\author{
Kieran M. Stanley ${ }^{1}$, Aoife Grant ${ }^{1}$, Simon O'Doherty ${ }^{1}$, Dickon Young ${ }^{1}$, Alistair J. Manning ${ }^{1,2}$, Ann R. Stavert ${ }^{1, \text { a }}$, \\ T. Gerard Spain ${ }^{3}$, Peter K. Salameh ${ }^{4}$, Christina M. Harth ${ }^{4}$, Peter G. Simmonds ${ }^{1}$, William T. Sturges ${ }^{5}$, \\ David E. Oram ${ }^{5}$, and Richard G. Derwent ${ }^{6}$ \\ ${ }^{1}$ School of Chemistry, University of Bristol, Bristol, UK \\ ${ }^{2}$ Met Office, Exeter, Devon, UK \\ ${ }^{3}$ Department of Experimental Physics, National University of Ireland, Galway, Ireland \\ ${ }^{4}$ Scripps Institution of Oceanography, University of California San Diego, La Jolla, California, USA \\ ${ }^{5}$ School of Environmental Sciences, University of East Anglia, Norwich, UK \\ ${ }^{6}$ rdscientific, Newbury, Berkshire, UK \\ ${ }^{a}$ now at: CSIRO Oceans and Atmosphere, Aspendale, Victoria, Australia
}

Correspondence: Kieran M. Stanley (k.m.stanley@bristol.ac.uk)

Received: 26 September 2017 - Discussion started: 20 October 2017

Revised: 18 January 2018 - Accepted: 5 February 2018 - Published: 14 March 2018

\begin{abstract}
A network of three tall tower measurement stations was set up in 2012 across the United Kingdom to expand measurements made at the long-term background northern hemispheric site, Mace Head, Ireland. Reliable and precise in situ greenhouse gas (GHG) analysis systems were developed and deployed at three sites in the UK with automated instrumentation measuring a suite of GHGs. The UK Deriving Emissions linked to Climate Change (UK DECC) network uses tall $(165-230 \mathrm{~m})$ open-lattice telecommunications towers, which provide a convenient platform for boundary layer trace gas sampling. In this paper we describe the automated measurement system and first results from the UK DECC network for $\mathrm{CO}_{2}, \mathrm{CH}_{4}, \mathrm{~N}_{2} \mathrm{O}, \mathrm{SF}_{6}, \mathrm{CO}$ and $\mathrm{H}_{2}$.

$\mathrm{CO}_{2}$ and $\mathrm{CH}_{4}$ are measured at all of the UK DECC sites by cavity ring-down spectroscopy (CRDS) with multiple inlet heights at two of the three tall tower sites to assess for boundary layer stratification. The short-term precisions ( $1 \sigma$ on 1 min means) of CRDS measurements at background mole fractions for January 2012 to September 2015 is $<0.05 \mu \mathrm{mol} \mathrm{mol}^{-1}$ for $\mathrm{CO}_{2}$ and $<0.3 \mathrm{nmol} \mathrm{mol}^{-1}$ for $\mathrm{CH}_{4}$. Repeatability of standard injections $(1 \sigma)$ is $<0.03 \mu \mathrm{mol} \mathrm{mol}^{-1}$ for $\mathrm{CO}_{2}$ and $<0.3 \mathrm{nmol} \mathrm{mol}^{-1}$ for $\mathrm{CH}_{4}$ for the same time period. $\mathrm{N}_{2} \mathrm{O}$ and $\mathrm{SF}_{6}$ are measured at three of the sites, and $\mathrm{CO}$ and $\mathrm{H}_{2}$ measurements are made at two of the sites, from a single inlet height us-
\end{abstract}

ing gas chromatography (GC) with an electron capture detector (ECD), flame ionisation detector (FID) or reduction gas analyser (RGA). Repeatability of individual injections $(1 \sigma)$ on GC and RGA instruments between January 2012 and September 2015 for $\mathrm{CH}_{4}, \mathrm{~N}_{2} \mathrm{O}, \mathrm{SF}_{6}, \mathrm{CO}$ and $\mathrm{H}_{2}$ measurements were $<2.8 \mathrm{nmol} \mathrm{mol}^{-1},<0.4 \mathrm{nmol} \mathrm{mol}^{-1}$, $<0.07 \mathrm{pmol} \mathrm{mol}^{-1},<2 \mathrm{nmol} \mathrm{mol}^{-1}$ and $<3 \mathrm{nmol} \mathrm{mol}^{-1}$, respectively.

Instrumentation in the network is fully automated and includes sensors for measuring a variety of instrumental parameters such as flow, pressures, and sampling temperatures. Automated alerts are generated and emailed to site operators when instrumental parameters are not within defined set ranges. Automated instrument shutdowns occur for critical errors such as carrier gas flow rate deviations.

Results from the network give good spatial and temporal coverage of atmospheric mixing ratios within the UK since early 2012. Results also show that all measured GHGs are increasing in mole fraction over the selected reporting period and, except for $\mathrm{SF}_{6}$, exhibit a seasonal trend. $\mathrm{CO}_{2}$ and $\mathrm{CH}_{4}$ also show strong diurnal cycles, with night-time maxima and daytime minima in mole fractions. 


\section{Introduction}

Carbon dioxide $\left(\mathrm{CO}_{2}\right)$, methane $\left(\mathrm{CH}_{4}\right)$, nitrous oxide $\left(\mathrm{N}_{2} \mathrm{O}\right)$, sulfur hexafluoride $\left(\mathrm{SF}_{6}\right)$, and carbon monoxide $(\mathrm{CO})$ are potent greenhouse gases (GHGs), which have a significant influence on the earth's climate system (Stocker et al., 2013). $\mathrm{H}_{2}$ is an important indirect GHG, due to its photochemical reaction with hydroxyl radicals $(\mathrm{OH})$ in the troposphere, reducing $\mathrm{OH}$ mole fractions, thus increasing the lifetime of $\mathrm{CH}_{4}$ and affecting ozone production (Grant et al., 2010a, b; Luan et al., 2016). Atmospheric mole fractions of $\mathrm{CO}_{2}, \mathrm{CH}_{4}$, $\mathrm{N}_{2} \mathrm{O}, \mathrm{SF}_{6}$ and $\mathrm{CO}$ have all exceeded pre-industrial levels due to anthropogenic activities (Kirschke et al., 2013; Stocker et al., 2013; Le Quéré et al., 2015). The increased concern about rising GHG emissions has already caused many nations to regulate their emissions. Inversion modelling techniques using data from atmospheric measurements can be used to derive emissions (Manning et al., 2011) and verify the national GHG inventories created using bottom up approaches; however, the accuracy of the inversion is limited by the number and distribution of measurement locations available, as well as the capacity to properly represent observed time series data.

Remote measurements of GHGs first started in the 1950s at the Mauna Loa Observatory, Hawaii, USA. Remote background locations were chosen as to avoid strong anthropogenic sources encountered at stations close to populated regions which made data interpretation more difficult at the time (Keeling et al., 1976; Popa et al., 2010). Other background stations followed in the decades after Mauna Loa was set up, such as at Baring Head, New Zealand, in 1970 (Brailsford et al., 2012) and the Atmospheric Life Experiment (ALE, a predecessor to the current Advanced Global Atmospheric Gases Experiment, AGAGE) in 1978 (Prinn et al., 2000). Measurements from these background stations only constrained estimations of global or hemispheric-scale fluxes within inverse models and were not able to capture local to regional scales (Gloor et al., 2001). Tall tower measurements in conjunction with transport models were proposed as a means to estimate local to regional-scale GHG fluxes (Tans, 1993). GHG measurements from tall towers began in the 1990s (Haszpra et al., 2001; Popa et al., 2010) and have been expanded in the 2000s as part of a number of national and international measurement campaigns (Vermeulen, 2007; Kozlova et al., 2008; Thompson et al., 2009; Popa et al., 2010). Measurements made from ground level at terrestrial sites often display complex atmospheric signals with source and sink interactions visible. Sampling from tall towers reduces the influence of these local effects (Gerbig et al., 2003, 2009).

For over 30 years, high-frequency measurements of GHGs have been made at Mace Head (MHD), a global background measurement station on the west coast of Ireland. MHD predominantly receives well-mixed air masses, which have travelled across the northern Atlantic, in the prevail- ing south-westerly winds, providing a good mid-latitude Northern Hemisphere background signal. These in situ, highfrequency, high-precision measurements have been used to estimate emissions of GHGs from the UK using the Inversion Technique for Emission Modelling (InTEM) methodology (Manning et al., 2011). In 2011, the UK government funded the establishment and integration of three new tall tower measurements stations in the UK. The UK Deriving Emissions linked to Climate Change (UK DECC) network was established to monitor the atmospheric mole fractions of GHGs, improve the spatial and temporal distribution of measurements across the UK and improve GHG emission estimates for comparison with the national inventory; see Manning et al. (2011) for more details. The new network became operational in 2012. Of the four atmospheric monitoring stations, two main stations (MHD and Tacolneston: TAC) measure a suite of $\sim 50 \mathrm{GHGs}$ and ozone-depleting substances (ODSs; Table 1), while the two other stations (Ridge Hill: RGL; Angus: TTA) measure the key GHGs. $\mathrm{CO}_{2}, \mathrm{CH}_{4}, \mathrm{~N}_{2} \mathrm{O}$, $\mathrm{SF}_{6}, \mathrm{CO}$ and $\mathrm{H}_{2}$ are the main focus of this paper. $\mathrm{CO}_{2}$ and $\mathrm{CH}_{4}$ are measured at all stations at high frequency $(\sim 3 \mathrm{~s})$, whilst $\mathrm{N}_{2} \mathrm{O}, \mathrm{SF}_{6}, \mathrm{CO}$ and $\mathrm{H}_{2}$ are measured at a lower frequency (detailed in Sect. 3).

The main objective of this paper is to describe an automated, reliable and high-precision analysis system for routine unattended monitoring of atmospheric $\mathrm{CO}_{2}, \mathrm{CH}_{4}, \mathrm{~N}_{2} \mathrm{O}$, $\mathrm{SF}_{6}, \mathrm{CO}$, and $\mathrm{H}_{2}$ within the UK. We focus on the technical details of the network, review the performance of and present first results from the network.

\section{Site location}

The location of the three tall tower UK DECC stations was designed to provide good spatial measurement coverage across the UK utilising open-lattice tall towers. Good spatial coverage was necessary to provide information on emissions from the UK's devolved administrative regions of Scotland, Wales, England and Northern Ireland. The network consists of four sites all measuring key GHGs (Table 1). Instruments at the Irish coastal site at MHD take whole air samples from $10 \mathrm{~m}$ above ground level (m a.g.l.), whilst the three UK sites sample from differing heights on tall telecommunications towers (45-222 $\mathrm{m}$ a.g.1.). The site locations and descriptions are given in Fig. 1 and Table 2, respectively. Minor instrumental changes have occurred within the network lifetime; however, the described instrumentation at the sites is correct as of September 2015.

\subsection{Mace Head (MHD)}

The MHD atmospheric research station is one of only a few western European stations that for significant periods of time is representative of mid-latitude northern hemispheric background air and provides an essential baseline input for the 
Table 1. Greenhouse gas and ozone-depleting substance species and instrumentation at each UK DECC site.

\begin{tabular}{lllll}
\hline \multirow{2}{*}{ Species } & \multicolumn{4}{c}{ Sites } \\
\cline { 2 - 5 } & $\begin{array}{l}\text { Mace Head } \\
(\text { MHD) }\end{array}$ & $\begin{array}{l}\text { Tacolneston } \\
\text { (TAC) }\end{array}$ & $\begin{array}{l}\text { Ridge Hill } \\
\text { (RGL) }\end{array}$ & $\begin{array}{l}\text { Angus } \\
\text { (TTA) }\end{array}$ \\
\hline $\mathrm{CO}_{2}$ & Picarro 2301 $^{\mathrm{a}}$ & Picarro G2301 & Picarro G2301 & Picarro G2301 \\
$\mathrm{CH}_{4}$ & GC-FID $^{\mathrm{b}}$ & Picarro G2301 & Picarro G2301 & Picarro G2301 \\
$\mathrm{N}_{2} \mathrm{O}$ & GC-ECD $^{\mathrm{O}}$ & GC-ECD & GC-ECD & - \\
$\mathrm{SF}_{6}$ & Medusa $^{\mathrm{c}}$ & GC-ECD/Medusa & GC-ECD & - \\
$\mathrm{H}_{2}$ & GC-RGA & GC-RGA & - & - \\
$\mathrm{CO}$ & GC-RGA & GC-RGA & - & - \\
\hline
\end{tabular}

a Picarro G2301 instruments on site are owned and managed by Laboratoire des Sciences du Climat et de l'Environnement (LSCE), France. Data are available through the ICOS Carbon Portal

(https://www.icos-cp.eu/). ${ }^{\mathrm{b}} \mathrm{CH}_{4}$ is also analysed on the Picarro G2301 instrument maintained by LSCE. Data are available through the ICOS Carbon Portal (https://www.icos-cp.eu/). ${ }^{c}$ Other ozone-depleting species measured on the Medusa GC-MS can be found in Miller et al. (2008) and Arnold et al. (2012).

Table 2. Site names, locations and inlet heights.

\begin{tabular}{lllrr}
\hline Site name & Acronym & Location & $\begin{array}{r}\text { Altitude* } \\
(\mathrm{m} \text { a.s.1. })\end{array}$ & $\begin{array}{r}\text { Inlet heights } \\
\text { (m a.g.1.) }\end{array}$ \\
\hline Mace Head & MHD & $53.327^{\circ} \mathrm{N}, 9.904^{\circ} \mathrm{W}$ & 8 & 10 \\
Ridge Hill tower & RGL & $51.998^{\circ} \mathrm{N}, 2.540^{\circ} \mathrm{W}$ & 204 & 45,90 \\
Tacolneston tower & TAC & $52.518^{\circ} \mathrm{N}, 1.139^{\circ} \mathrm{E}$ & 56 & $54,100,185$ \\
Angus tower & TTA & $56.555^{\circ} \mathrm{N}, 2.986^{\circ} \mathrm{W}$ & 400 & 222 \\
\hline
\end{tabular}

* Altitude measured at base of tower.

UK DECC network. At the station (Fig. 1), numerous ambient air measurements are made as part of the AGAGE (Cunnold et al., 1997; Prinn et al., 2000), Integrated Carbon Observation System (ICOS; Vardag et al., 2014) and the Global Atmospheric Watch (GAW) networks. Prevailing winds from the west to southwest sector bring well-mixed background Atlantic air to the site on average $51 \%$ of the time (Jennings et al., 2003). Polluted European air masses, as well as tropical maritime air masses, cross the site periodically. MHD is uniquely positioned to observe these different air masses. Galway, the closest city, has a population of $\sim 75000$ and lies $55 \mathrm{~km}$ to the east. The area immediately surrounding MHD is very sparsely populated, providing very low local anthropogenic emissions. The area surrounding MHD is generally wet and boggy with areas of exposed rock (Dimmer et al., 2001). The sample inlet is located $90 \mathrm{~m}$ inland from the shoreline ( $5 \mathrm{~m}$ above sea level; $\mathrm{ma.s.1}$.) and samples air from $10 \mathrm{~m}$ a.g.l. $\mathrm{CH}_{4}$ and $\mathrm{N}_{2} \mathrm{O}$ measurements started at MHD on 23 January 1987. $\mathrm{CO}$ and $\mathrm{H}_{2}$ measurements were added on 17 February 1994, and $\mathrm{SF}_{6}$ measurements were included on 15 November 2003. A fully synoptic weather station operated by Met Eireann is located $\sim 300 \mathrm{~m}$ from shore at $21 \mathrm{~m}$ a.s.1.

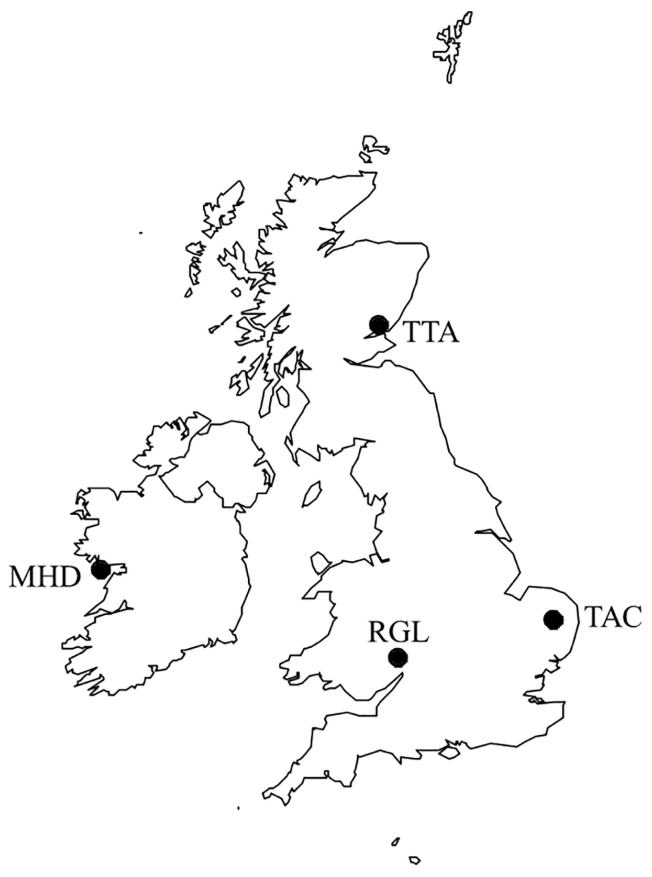

Figure 1. Location of UK DECC network stations, showing from north to south: TTA, Angus, UK; MHD, Mace Head, Ireland; TAC, Tacolneston, UK; and RGL, Ridge Hill, UK. 


\subsection{Ridge Hill (RGL)}

RGL is a rural UK site located $30 \mathrm{~km}$ east from the border of England and Wales (Fig. 1). It is $16 \mathrm{~km}$ south-east of Hereford (population 55800 ), and $30 \mathrm{~km}$ south-west of Worcester (population 98 800), in Herefordshire, UK (ONS, 2012). The land surrounding the tower is primarily used for agricultural purposes and there are 25 waste water treatment plants within a $40 \mathrm{~km}$ radius of the site, the majority of which are in the northeast to south-easterly wind sector (DEFRA, 2012). Air samples are taken from inlet lines located at 45 and $90 \mathrm{~m}$ a.g.l. from a tall open-lattice telecommunications tower at 204 m a.s.l. $\mathrm{N}_{2} \mathrm{O}$ and $\mathrm{SF}_{6}$ measurements started on 1 March 2012 and are measured from $90 \mathrm{~m}$ a.g.l. only, whilst $\mathrm{CO}_{2}$ and $\mathrm{CH}_{4}$ are measured from both heights sequentially and started on 23 February 2012.

\subsection{Tacolneston (TAC)}

TAC is a rural UK site located towards the east coast of England (Fig. 1). It is $16 \mathrm{~km}$ south-west of Norwich (population 200000 ), and $28 \mathrm{~km}$ east of Thetford (population 20000), in Norfolk, UK (ONS, 2012). Lines sample air at 54, 100, and $185 \mathrm{~m}$ a.g.l. from a tall open-lattice telecommunications tower at $56 \mathrm{~m}$ a.s.l. $\mathrm{CO}_{2}$ and $\mathrm{CH}_{4}$ measurements started on 26 July 2012 and are measured from all three heights sequentially, whilst all other GHGs and ODSs (Table 1) are measured from the $100 \mathrm{~m}$ a.g.l. inlet only. This inlet was chosen as when the site was set up in 2012 , the $185 \mathrm{~m}$ a.g.l. inlet had not yet been installed and came on line in January 2013. $\mathrm{N}_{2} \mathrm{O}, \mathrm{SF}_{6}, \mathrm{CO}$ and $\mathrm{H}_{2}$ measurements started on 26 July 2012. Land surrounding the tower is primarily used for agriculture, which is dominated by arable farming. Out of a total farmed area of over 400000 ha, $79 \%$ of this is used in arable farming (DEFRA, 2010). There are three landfill sites between 30 and $50 \mathrm{~km}$ from the site, the closest being $30 \mathrm{~km}$ to the east (Environment Agency, 2017). There is also a poultry litter power station in Eye, $20 \mathrm{~km}$ south of the site (MREUK, 2016).

\subsection{Angus (TTA)}

TTA is a rural UK site located near the east coast of Scotland (Fig. 1). It is $10 \mathrm{~km}$ north of Dundee (population 148000 ; GRO, 2013). A single line samples air at $222 \mathrm{~m}$ a.g.l. from the tall open-lattice tower at 400 ma.s.l., which measures $\mathrm{CO}_{2}$ and $\mathrm{CH}_{4}$. Land surrounding the tower is predominantly under agricultural use, primarily livestock farming due to its hilly terrain. A Picarro G2301 was installed on 29 May 2013 and all TTA data reported in this paper are from 29 May 2013 to 30 September 2015 only.

\section{Instrumentation}

GHG measurement systems were developed in 2011 and then deployed in 2012 to enable measurements of GHGs from telecommunication towers within the UK. The system designs are similar to sampling equipment already deployed at Mace Head (Prinn et al., 2000) and at other tall tower sites (Popa et al., 2010; Winderlich et al., 2010). The systems are designed to utilise easily obtainable parts, so that rapid replacement is possible on component failure, thus minimising system downtime and data gaps. This section outlines the instrumental setup used within the UK DECC network to measure GHGs. Table 1 summarises the trace gas species measured at each of the sites and the instrumentation used. Figure 2 shows a schematic diagram for TTA, RGL and TAC, whereas the MHD setup is outlined in Prinn et al. (2000).

\subsection{Sample tubing}

At all UK DECC sites, instrumentation is located at the base of the towers in a building or a modified shipping container. At RGL and TAC, air is sampled through $1 / 2$ in. O.D. "Synflex 1300" or "Dekabon" tubing (Hose Tech Ltd, UK), whilst at TTA, it is sampled through $3 / 8$ in. "Synflex 3000" tubing (Andrews et al., 2014). Air at MHD is sampled through $1 / 4$ in. stainless steel tubing (304 stainless steel, 1/4 in. O.D., 0.209 in. I.D., Supelco, Sigma-Aldrich, UK). For the number of inlets at each site, please refer to Sect. 2. Tubing is held in place using UV-resistant plastic clips or cable ties and runs down vertical metal tubes on the tower. Horizontal sections of tubing at the base of the tower were kept to a minimum and low points were avoided to prevent the accumulation of water $\left(\mathrm{H}_{2} \mathrm{O}\right)$. For each inlet at RGL and TAC, an inverted stainless steel cup with a Monel mesh screen inserted within the cup covers the inlet, acting as a shield to prevent $\mathrm{H}_{2} \mathrm{O}$ entering the line. The mesh screen was removed from the inlet cups at RGL in September 2013 as it was thought that $\mathrm{H}_{2} \mathrm{O}$ was accumulating on the mesh and then being sucked into the inlet lines. This effect of the mesh promoting $\mathrm{H}_{2} \mathrm{O}$ entering the inlet lines has not been observed at TAC and the mesh is still in place. $\mathrm{H}_{2} \mathrm{O}$ decanting bowls with coalescing filter (Norgren, model F74G-4GN-QP3; wetted parts include aluminium housing, Perspex bowl, sintered $40 \mu \mathrm{m}$ polypropylene filter and nitrile and neoprene O-rings) are fitted to each sample line at its lowest point at the base of the tower to ensure that liquid $\mathrm{H}_{2} \mathrm{O}$ does not enter the laboratory and instrumentation. Perspex $\mathrm{H}_{2} \mathrm{O}$ decanting bowls were first tested in the UoB laboratory to check for non-contamination of measurements. The $\mathrm{H}_{2} \mathrm{O}$ traps at site are checked on a weekly to monthly basis and emptied manually using a toggle valve at the base of the decanting bowl.

Once the sample lines enter the laboratory, whole air samples pass through an inline $40 \mu \mathrm{m}$ filter (SS-8TF-40, Swagelok, UK) to trap larger particles and then a $7 \mu \mathrm{m}$ filter (SS-4F-7, Swagelok, UK) on the branched secondary instrument lines, according to the details in Fig. 2. Filters were not installed on the tower inlets to prevent blockages from ice and subsequence system downtime. Unless stated otherwise, 
TTA
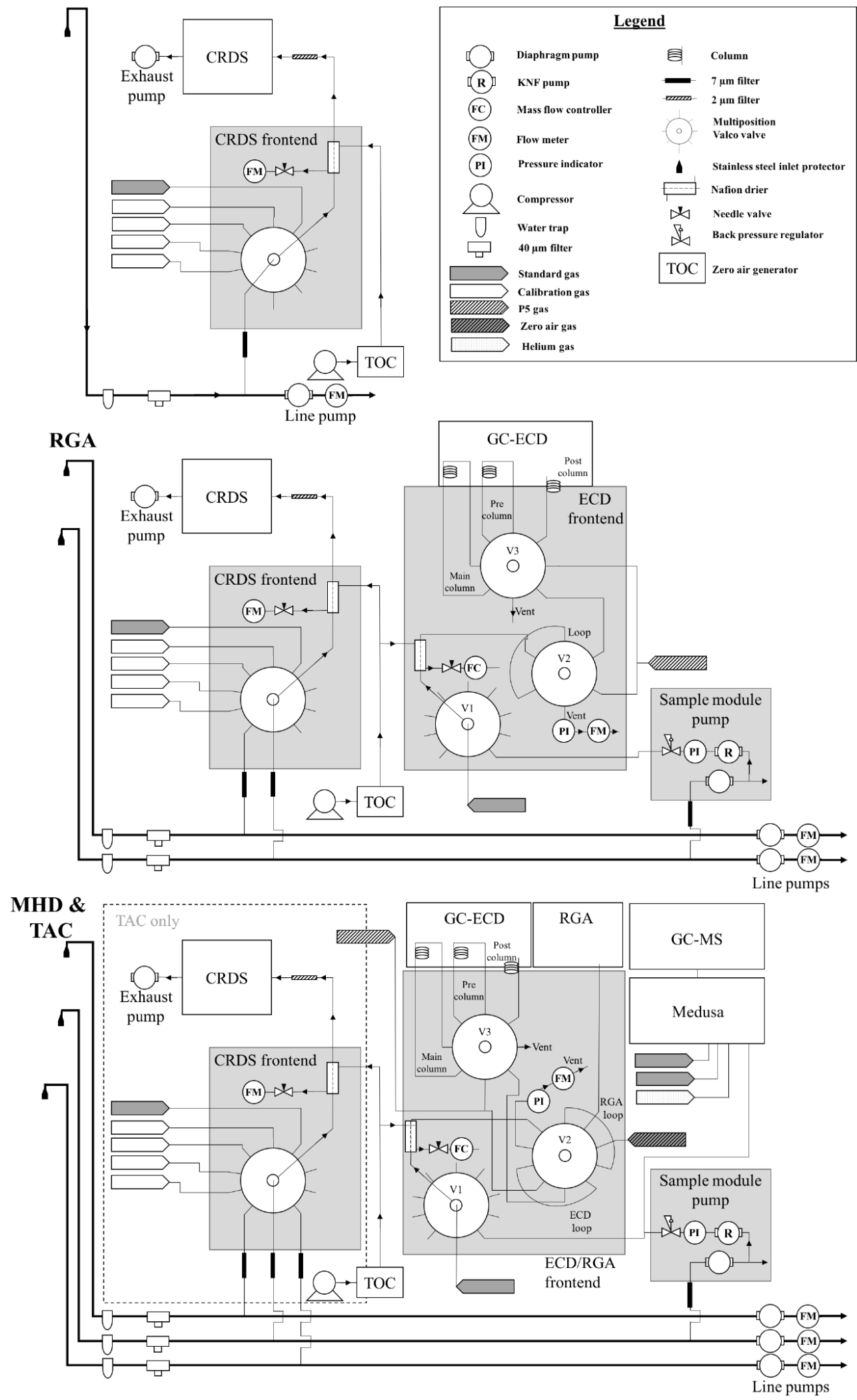

Figure 2. Schematic diagram of the UK DECC network (Angus, TTA; Ridge Hill, RGL; and Tacolneston, $\mathrm{TAC}_{\text {) }} \mathrm{CO}_{2}, \mathrm{CH}_{4}, \mathrm{~N}_{2} \mathrm{O}, \mathrm{SF}_{6}, \mathrm{CO}$ and $\mathrm{H}_{2}$ analysis system. The MHD setup is outlined in Prinn et al. (2000). 
tubing within the laboratories is $1 / 4 \mathrm{in}$. O.D., $0.209 \mathrm{in}$. I.D. 304 stainless steel (Supelco, Sigma-Aldrich, UK).

The sample line setup at TTA was different to the two other UK sites (RGL and TAC) as this site had previously been managed by the University of Edinburgh before being transferred to the University of Bristol (UoB) from January 2013. Specific differences at TTA include that the sample inlet does not have a protective cup covering it (the air sampling line is cut on a bias so $\mathrm{H}_{2} \mathrm{O}$ has a drip point) and that the $\mathrm{H}_{2} \mathrm{O}$ trap at the base of the tower is stainless steel rather than Perspex.

\subsection{Pumps}

Each sample line has its own dedicated oil-less linear pump (DBM20-801, GAST Group Ltd, UK; TTA: Capex L2, Charles Austin, UK), continuously flushing at a flow rate of $\sim 20 \mathrm{~L} \mathrm{~min}^{-1}$, located downstream of all sampling equipment. Flow is measured downstream of the sample line pump using flow meters (VFB-68, 3-30 $\mathrm{L} \mathrm{min}^{-1}$, Dwyer, UK) and vented into the laboratory. The continuous flushing of the inlet lines results in residence times within the tubing of between 7 and $35 \mathrm{~s}$, depending on sampling height, from air intake to the instrumentation. At MHD, air is flushed at a flow rate of $5 \mathrm{~L} \mathrm{~min}^{-1}$, with instruments sampling at rates between 100 and $110 \mathrm{~mL} \mathrm{~min}^{-1}$. At TTA the sample line pump has a flow rate of $8.5 \mathrm{~L} \mathrm{~min}^{-1}$. Branched secondary lines subsample from the main samples lines for all instruments (Fig. 2).

Cavity ring-down spectrometers (CRDSs) subsample from the main sample lines, passing through the sample selection system and a Nafion dryer (described in Sect. 3.3). CRDS instrument pumps (MD1 pump, Vacuubrand $\mathrm{GmbH} \& \mathrm{Co}$. KG, UK) are located downstream of the analyser. This has the advantage of eliminating sample contamination from the pump, reducing the likelihood of a torn diaphragm introducing laboratory air into the sample. The CRDS outlet valve pressure is monitored as a diagnostic for instrument pump failure. The CRDS instrument pump uses polytetrafluoroethylene (PTFE)/Viton ${ }^{\circledR}$ (also known as FKM) diaphragms. CRDS MD1 instrument pumps are located in the ambient internal laboratory air to allow efficient cooling from the fitted heat sink.

All gas chromatograph (GC) systems and reduction gas analysers (RGAs) use a similar line pump setup (described above), housed within a custom-built GC instrument sample module (Fig. 2). A KNF pump (N86 STE, KNF Neuberger UK Ltd, Oxfordshire, UK) is located downstream of the diaphragm pump, which subsamples at a flow rate of $6 \mathrm{~L} \mathrm{~min}^{-1}$. A Circor backpressure regulator (GO model LB12A01DCE171, Boiswood Ltd, UK) is used to control the KNF pump output pressure, which is viewed using a pressure gauge (0-60 psi Wika, Cole Palmer Instrument Co, UK) and a flowmeter (0.2-4 $\mathrm{L} \mathrm{min}^{-1}$, VFB-65, Dwyer, UK). This design enables the supply pressure of the air and standard to be matched and prevent pressure artefacts on the columns. Pressure and flow into the sample selection system is monitored by electronic pressure transducers and flow meters (details in Sect. 3.4), meaning that the GC sample module performance can be monitored remotely and failures can be easily diagnosed.

\subsection{Cavity ring-down spectrometer}

$\mathrm{CO}_{2}$ and $\mathrm{CH}_{4}$ measurements at RGL, TAC and TTA are made using G2301 (Picarro Inc., USA) CRDS analysers (Tremblay et al., 2004; Crosson, 2008). Custom-made sample selection systems made at the UoB are used to switch between air inlets, calibration and standard gases for CRDS analysis, in addition to drying the samples (Fig. 2). The sample selection system consists of a 10-port multi-position valve (EUTACSD10MWEPH, VICI Valco AG International, Switzerland) to direct samples through the Nafion permeation dryer and to the CRDS. All air inlets and calibration gases are plumbed into the multi-position valve for ease of use and sample selection. Automatic sampling is achieved by controlling the multi-position valve using Linux-based software (GCWerks ${ }^{\mathrm{TM}}$, www.gcwerks.com). An inline $2 \mu \mathrm{m}$ filter (SS-4F-2, Swagelok, UK) is in place between the outlet of the frontend system and the inlet to the analyser (Fig. 2) to further remove any particles that may negatively affect the CRDS.

The CRDS systems measure the decay time of the pulse of laser light inside a $35 \mathrm{~cm}^{3}$ cavity at two wavelengths for ${ }^{12} \mathrm{C}^{16} \mathrm{O}_{2}(1651 \mathrm{~nm}),{ }^{12} \mathrm{CH}_{4}(1603 \mathrm{~nm})$ and $\mathrm{H}_{2}^{16} \mathrm{O}(1603 \mathrm{~nm})$ (Winderlich et al., 2010). Mole fraction measurements of each gas are provided at a frequency of $\sim 3 \mathrm{~s}$. Sample flow, temperature $(318 \pm 0.004 \mathrm{~K})$ and pressure $(140 \pm 0.05$ Torr $)$ are maintained at specific set points as the size and shape of the spectral lines are sensitive to both temperature and pressure. The analyser is thus designed to control temperature to a few thousandths of a kelvin from 10 to $35^{\circ} \mathrm{C}$ and sample pressure to 0.05 Torr.

$\mathrm{H}_{2} \mathrm{O}$ can damage system components and interfere with measurements of GHGs, even at low levels, through a dilution effect (Andrews et al., 2014) and pressure broadening effects (Chen et al., 2010; Rella et al., 2013). To minimise these effects, samples were dried to $<0.25 \%\left(<-10.3{ }^{\circ} \mathrm{C}\right.$ dew point) using permeation Nafion dryers (MD-050-72S-1, Perma Pure, USA) housed within the sample selection systems. Dried zero air is used as the counter purge at $20 \mathrm{psi}$, supplied by a compressor (JUN-AIR, model 2000, Norgren, Denmark at TAC and RGL, or DK50 plus, Ekom, Slovak Republic, at TTA) connected to a zero-air generator (TOC1250, Parker Balston, USA).

In addition to using permeation Nafion dryers, a data correction can also be applied to remove spectral effects caused by $\mathrm{H}_{2} \mathrm{O}$ for CRDS systems. All CRDSs in the network produce data corrected for the $\mathrm{H}_{2} \mathrm{O}$ effects, using the correction coefficients listed in Rella (2010). The correction applied is minimised due to the removal of most $\mathrm{H}_{2} \mathrm{O}$ using the Nafion dryer. TTA air samples were not dried prior to 
measurement until a Nafion drying system was installed in September 2014.

The CRDS instruments at TAC and RGL were fully operational for $>98 \%$ for the time period reported here. The TTA CRDS was operational for $>93 \%$. The inlet at Angus was not shielded from rainwater by an inverted cup, as was the case at other sites, and access to the site was more difficult due to its remote location. As a result, the $\mathrm{H}_{2} \mathrm{O}$ trap filled up more frequently, resulting in more ambient air data being rejected.

\subsection{Gas chromatograph-electron capture detector}

$\mathrm{N}_{2} \mathrm{O}$ and $\mathrm{SF}_{6}$ were measured using gas chromatography coupled with micro-electron capture detectors (GC-ECD) at RGL and TAC with a similar instrumental setup (specific setup outlined in Table 3). A simplified schematic diagram for the GC-ECD systems at RGL and TAC is shown in Fig. 2. The GC-ECD at MHD measured $\mathrm{N}_{2} \mathrm{O}$ using a different experimental setup, details of which can be found in Prinn et al. (2000), alongside details of the GC-FID instrument which measures $\mathrm{CH}_{4}$ at Mace Head.

The $\mathrm{SF}_{6}$ and $\mathrm{N}_{2} \mathrm{O}$ analysis method used at RGL and TAC was similar to that described in detail in Ganesan et al. (2013), except that P-5 carrier gas (a mixture of $5 \% \mathrm{CH}_{4}$ in $95 \%$ Ar; Air Products, UK) is used (Schmidt et al., 2001). Briefly, calibration gas and air samples are flushed through an $8 \mathrm{~mL}$ sample loop at $40 \mathrm{~mL} \mathrm{~min}^{-1}$ for $60 \mathrm{~s}$ at a fixed exhaust pressure ( 20 psi; Fig. 3, "Backflush") before decaying down to ambient pressure. Flow through the loop is controlled by a "RED-y" smart series mass flow controller (GSC-A4TA-BB22, Voeglin Instruments AG, Switzerland) and pressure in the loop is measured using an "All Sensor" pressure sensor (100PSI-A-DO, All Sensors, BS-Rep GmbH, Germany). Once equilibrated to ambient pressure, samples are then injected through an eight-port, two-position valve (V3 in Fig. 2; EUDAC8UWEPH, VICI Valco AG International, Switzerland) onto a pre-column (1.0 m Porapak Q, 80/100 mesh, 3/16 in. O.D.) and main column (2.0 m Porapak Q, 80/100 mesh, 3/16 in. O.D.) held at $90^{\circ} \mathrm{C}$, where $\mathrm{N}_{2} \mathrm{O}$ and $\mathrm{SF}_{6}$ are separated from air. Oxygen is "heart-cut" to vent (V3, Fig. 3) after it has eluted from the two columns, whilst the pre-column is back flushed with P5. The remaining, $\mathrm{O}_{2}$-minimised, sample flows through the post-column ( $0.9 \mathrm{~m}$ of $1 / 8$ in. O.D. stainless steel packed with molecular sieve $5 \AA, 45 / 60$ mesh), housed in a thermostatically controlled heated inlet port of the $\mathrm{GC}$ at $180^{\circ} \mathrm{C}$. The post column reverses the elution order of $\mathrm{SF}_{6}$ and $\mathrm{N}_{2} \mathrm{O}$ to prevent the larger $\mathrm{N}_{2} \mathrm{O}$ peak from tailing into the small $\mathrm{SF}_{6}$ peak, improving sample reproducibility and precision. Detection occurs in the ECD which is held at $350^{\circ} \mathrm{C}$. The ECDs at TAC and RGL measure at a rate of 10 and $20 \mathrm{~Hz}$, respectively. Samples are dried using a Nafion dryer (MD-050-72S1, Perma Pure, USA) with a dry zero-air counter purge (as outlined in Sect. 3.3).
The main difference between the method used in our systems and those described by Hall et al. (2011) is the use of $\mathrm{P} 5$ carrier gas instead of $\mathrm{CO}_{2}$-doped $\mathrm{N}_{2} \cdot \mathrm{N}_{2} \mathrm{O}$ co-elutes with $\mathrm{CO}_{2}$ on the post-column, saturating the MS $5 \AA$ and providing a constant doping effect and reducing precision. Purity of the P5 carrier gas has previously been an issue where certain cylinders were found to be contaminated with $\mathrm{SF}_{6}$ in varying amounts (5-80 $\mathrm{pmol} \mathrm{mol}^{-1}$, or parts per trillion, ppt). On average, one cylinder in every six has been contaminated with $\mathrm{SF}_{6}$ across the network but is dependent on cylinder age as the gas was used to leak test cylinders. Each cylinder is now individually analysed as a sample to check for contamination prior to use.

The three valves (Valco universally actuated, RS-232 communication, purged housing) are controlled remotely using GCWerks, enabling automatic sampling (see Sect. 3.8).

\subsection{Reduction gas analyser}

$\mathrm{CO}$ and $\mathrm{H}_{2}$ are measured at two sites, MHD and TAC, using a RGA (RGA3 (MHD) and Peak Performer 1 (TAC), Trace Analytical Inc., USA). Table 4 outlines RGA instrumental setup at TAC and MHD. The MHD RGA setup is different to TAC and is outlined in (Prinn et al., 2000). The TAC sample selection system is integrated within the GC-ECD system (Sect. 3.4; Grant et al., 2010a, b). The GC-ECD has a 10-port, two-position valve (VICI Valco AG International, Switzerland) for V2 (Fig. 2), instead of an eight-port two-position valve, as at RGL. This allows for a $1 \mathrm{~mL} \mathrm{RGA} \mathrm{sample} \mathrm{loop} \mathrm{to}$ be put in sequence before the ECD sample loop (Fig. 3 TAC). After samples have been dried using the Nafion dryer (MD050-72S-1, Perma Pure, USA), passed through the sample loops and decayed to ambient pressure, they are injected onto two isothermal packed columns held at $105^{\circ} \mathrm{C}$ : a $0.768 \mathrm{~m}$ pre-column (1/8 in. O.D. stainless steel packed with $60 / 80$ mesh Unibeads $1 \mathrm{~S})$ and a $0.768 \mathrm{~m}$ main column (1/8 in. O.D.

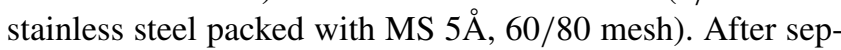
aration, gases are injected into the RGA for analysis using zero-air plus (Air Products, UK) carrier gas, where the samples pass over a heated bed of mercuric oxide before being quantitatively determined using UV photometry (Grant et al., 2010a, b).

\subsection{Medusa gas chromatograph-mass spectrometer}

The Medusa is a custom-built pre-concentration unit coupled to a gas chromatograph-mass spectrometer (GC-MS, the entire system is hereafter referred to as a Medusa GCMS), which measures a wide range of GHGs and ODSs. The Medusa GC-MS system is used at both MHD and TAC to measure $\mathrm{SF}_{6}$, amongst other compounds. A detailed description of the Medusa setup is presented in Miller et al. (2008) for TAC and Arnold et al. (2012) for the $\mathrm{NF}_{3}$ conversion (MHD setup). Briefly, a $2 \mathrm{~L}$ whole air sample is collected by the Medusa pre-concentration unit from the same sample 
Table 3. Gas chromatograph-flame ionisation and electron capture detector equipment and setup at UK DECC stations.

\begin{tabular}{|c|c|c|c|c|}
\hline & \multicolumn{2}{|c|}{ MHD } & \multirow{2}{*}{$\begin{array}{l}\text { TAC } \\
\text { ECD }\end{array}$} & \multirow{2}{*}{$\begin{array}{l}\text { RGL } \\
\text { ECD }\end{array}$} \\
\hline & FID & $\mathrm{ECD}^{*}$ & & \\
\hline Instrument & Carle AGC-211 & Hewlett-Packard 5890 & Agilent $6890 \mathrm{~N}$ & Agilent 7890A \\
\hline Detector & FID & ECD & $\mu \mathrm{ECD}$ & $\mu \mathrm{ECD}$ \\
\hline Sample volume & $10 \mathrm{~mL}$ & $8 \mathrm{~mL}$ & $8 \mathrm{~mL}$ & $8 \mathrm{~mL}$ \\
\hline Oven temperature & $60^{\circ} \mathrm{C}$ & $55^{\circ} \mathrm{C}$ & $90^{\circ} \mathrm{C}$ & $90^{\circ} \mathrm{C}$ \\
\hline Column temperature & $60^{\circ} \mathrm{C}$ & $\begin{array}{l}185^{\circ} \mathrm{C} \text { (pre) }, 55^{\circ} \mathrm{C} \\
\text { (main) }\end{array}$ & $\begin{array}{l}90^{\circ} \mathrm{C} \text { (pre and main), } \\
180^{\circ} \mathrm{C} \text { (post) }\end{array}$ & $\begin{array}{l}90^{\circ} \mathrm{C} \text { (pre and main), } \\
180^{\circ} \mathrm{C} \text { (post) }\end{array}$ \\
\hline Detector temperature & N/A & $325^{\circ} \mathrm{C}$ & $350^{\circ} \mathrm{C}$ & $350^{\circ} \mathrm{C}$ \\
\hline Pre-column & Silica gel & $\begin{array}{l}\text { Molecular sieve } 5 \AA \text {, } \\
60 / 80 \text { mesh }\end{array}$ & $\begin{array}{l}\text { Porapak Q, } \\
80 / 100 \text { mesh, } \\
1.0 \mathrm{~m} \times 3 / 16 \text { in.SS }\end{array}$ & $\begin{array}{l}\text { Porapak Q, } \\
80 / 100 \mathrm{mesh}, \\
1.0 \mathrm{~m} \times 3 / 16 \text { in.SS }\end{array}$ \\
\hline Main column & $\begin{array}{l}\text { Molecular sieve } 5 \AA \text {, } \\
60 / 80 \text { mesh }\end{array}$ & Porasil C & $\begin{array}{l}\text { Porapak Q, } \\
80 / 100 \text { mesh, } \\
2.0 \mathrm{~m} \times 3 / 16 \text { in.SS }\end{array}$ & $\begin{array}{l}\text { Porapak Q, } \\
80 / 100 \text { mesh, } \\
2.0 \mathrm{~m} \times 3 / 16 \text { in.SS }\end{array}$ \\
\hline Post-column & N/A & N/A & $\begin{array}{l}\text { Molecular sieve } 5 \AA \text {, } \\
45 / 60 \text { mesh, } \\
0.9 \mathrm{~m} \times 1 / 8 \text { in. }\end{array}$ & $\begin{array}{l}\text { Molecular sieve } 5 \AA \text {, } \\
45 / 60 \text { mesh, } \\
0.9 \mathrm{~m} \times 1 / 8 \text { in. }\end{array}$ \\
\hline Carrier gas supply & $\begin{array}{l}\mathrm{N}_{2} \text { cylinder } \\
(5.0)\end{array}$ & $\begin{array}{l}\mathrm{AR} / \mathrm{CH}_{4} \text { cylinder } \\
(95 \% / 5 \%)(5.0)\end{array}$ & $\begin{array}{l}\mathrm{AR} / \mathrm{CH}_{4} \text { cylinder } \\
(95 \% / 5 \%)(5.0)\end{array}$ & $\begin{array}{l}\mathrm{AR} / \mathrm{CH}_{4} \text { cylinder } \\
(95 \% / 5 \%)(5.0)\end{array}$ \\
\hline $\mathrm{H}_{2}$ supply & Cylinder (5.0) & N/A & N/A & N/A \\
\hline Zero-air supply & $\begin{array}{l}\text { TOC generator (Parker } \\
\text { Balston TOC-1250) }\end{array}$ & $\begin{array}{l}\text { TOC generator (Parker } \\
\text { Balston TOC-1250) }\end{array}$ & $\begin{array}{l}\text { TOC generator (Parker } \\
\text { Balston TOC-1250) }\end{array}$ & $\begin{array}{l}\text { TOC generator (Parker } \\
\text { Balston TOC-1250) }\end{array}$ \\
\hline
\end{tabular}

* Indicates $\mathrm{N}_{2} \mathrm{O}$ channel only on the MHD GC-ECD. N/A: not used within the specific system.

Table 4. Reduction gas analyser equipment and setup at UK DECC stations.

\begin{tabular}{lll}
\hline & MHD & TAC \\
\hline Instrument & Trace Analytical RGA3 & Trace Analytical PP1 \\
Detector & RGA & RGA \\
Sample volume & $1 \mathrm{~mL}$ & $1 \mathrm{~mL}$ \\
Column temperature & $105^{\circ} \mathrm{C}$ & $105^{\circ} \mathrm{C}$ \\
Pre-column & Unibeads $1 \mathrm{~S}, 60 / 80$ mesh, $0.768 \mathrm{~m} \times 1.8 \mathrm{in}$. & Unibeads $1 \mathrm{~S}, 60 / 80 \mathrm{mesh}, 0.768 \mathrm{~m} \times 1.8 \mathrm{in}$. \\
Main column & Molecular sieve $5 \AA$ A, $60 / 80$ mesh, $0.768 \mathrm{~m} \times 1.8 \mathrm{in}$. & Molecular sieve $5 \AA$ A $, 60 / 80 \mathrm{mesh}, 0.768 \mathrm{~m} \times 1.8 \mathrm{in}$. \\
Carrier gas supply & Zero-air cylinder $(5.5)+$ purifier & Zero-air cylinder $(5.5)+$ purifier \\
Zero-air supply & TOC generator (Parker Balston TOC-1250) & TOC generator (Parker Balston TOC-1250) \\
\hline
\end{tabular}

pump as the GC-ECD (outlined in Sect. 3.6; Fig. 2) wherein the sample is dried using two Nafion dryers (MD-050-72S-1, Perma Pure, USA) before being sequentially passed through two adsorbent traps cooled to $-165^{\circ} \mathrm{C}$ using a Cryotiger (Brooks Automation, Massachusetts, USA). More abundant gases (e.g. $\mathrm{N}_{2}, \mathrm{O}_{2}, \mathrm{CO}_{2}$ and $\mathrm{CH}_{4}$ ) are removed using temperature programming of the traps, allowing the trace species of interest to be isolated on the second refocusing trap after thermal desorption from the first trap. Trace gas species adsorbed on the second trap are released by heating the trap to $100{ }^{\circ} \mathrm{C}$ and passed through two columns (three columns for the $\mathrm{NF}_{3}$ method at $\mathrm{MHD}$ ) temperature programmed between 40 and $200{ }^{\circ} \mathrm{C}$ (Agilent $6890 \mathrm{GC}$, Agilent Technologies, UK) using helium carrier gas (MHD: BIP grade, Air Prod- ucts, UK; TAC: 6.0 grade, BOC, UK), separating out trace species chromatographically. Analytes are then detected via a quadrupole mass-selective detector (Agilent 5973, Agilent Technologies, UK) in selected ion monitoring (SIM) mode to increase sensitivity.

\subsection{Logging, control and ancillary equipment}

All instruments within the UK DECC network are controlled by GCWerks, installed on a local site computer running Ubuntu 12.04 LTS. GCWerks automates all instrument parameters (valves, trap and column temperatures, mass flow controllers, etc.), regulates switching processes, controls calibration cycles, displays chromatograms, performs peak integration and gives graphical and tabulated displays of all 


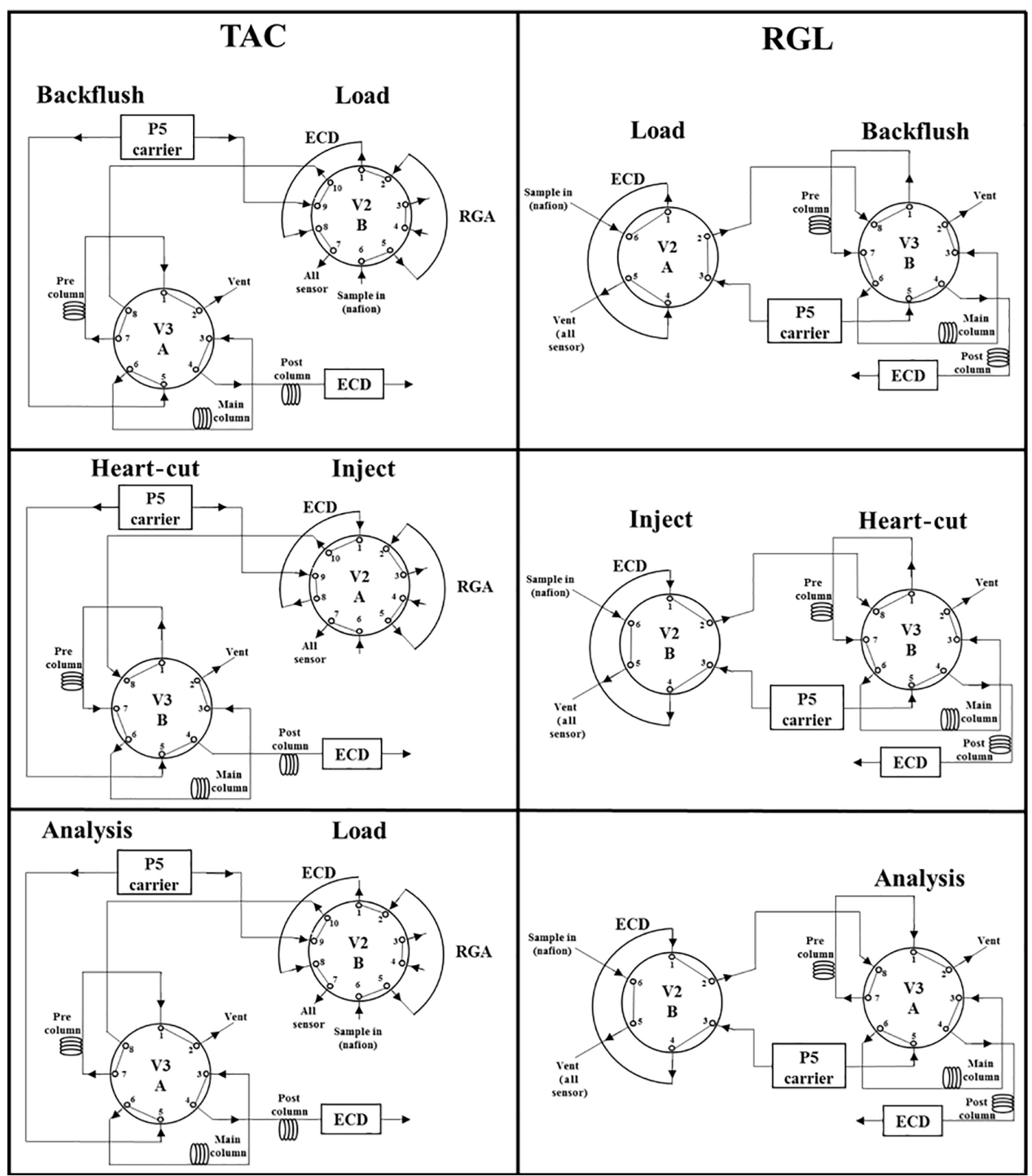

Figure 3. ECD frontend valve configuration for sample backflush, heart cut and analysis at Tacolneston (TAC) and Ridge Hill (RGL). The MHD setup is outlined in Prinn et al. (2000).

results. The automation of all instrumental processes helps to reduce problems and data loss associated with connection problems between independent sample modules to instruments.

GCWerks generates automated user-specified alarms when instrument parameter conditions are not met. These alarms can also initiate instrument shutdown when specified to prevent instrumental damage.

The local site computer is connected to CRDS and GC analysers via Ethernet and the sample selection systems communicate through serial (RS232) connections. Each site has a broadband internet connection which is utilised for remote access and control, automated data backup and maintaining system time synchronisation for each computer using the network time protocol. Data from instrumentation and ancillary equipment are logged and archived at all sites at a frequency of $0.3-20 \mathrm{~Hz}$.

Uninterruptible power systems (UPSs) are used at MHD (SG5K-6K, Falcon Electric Inc., USA), RGL and TAC (Sentinel Dual SDL8000, Riello UPS Ltd, UK) to prevent power surges and temporary power outages affecting instrumentation. The UPS provides up to $20 \mathrm{~min}$ of power to instrumentation in the event of a power outage. Additionally, an on-site generator provides continuous backup power at MHD with 
Table 5. Maintenance schedule for all UK DECC sites from January 2012 to September 2015. N/A: no emergency site visits were made.

\begin{tabular}{llrrrr}
\hline \multirow{2}{*}{ Site } & Scheduled visits & \multicolumn{4}{c}{ Emergency visits } \\
\cline { 3 - 6 } & & 2012 & 2013 & 2014 & 2015 \\
\hline MHD & 2-weekly & 1 & 1 & 1 & N/A \\
RGL & 6-weekly & 2 & 2 & 3 & 4 \\
TAC & 2-weekly & 2 & 2 & 2 & 3 \\
TTA & 8-weekly & N/A & 2 & 3 & 3 \\
\hline
\end{tabular}

the UPS providing power for long enough to enable a seamless transition of power from line to generator.

\subsection{Maintenance}

Maintenance schedules of each of the sites varies greatly depending on instrumentation; sites with Medusa GC-MSs (TAC and MHD) were visited more frequently due to the instrumentation being complicated and having greater maintenance needs and sites with only CRDSs were visited the least. Table 5 outlines routine site visits, as well as emergency visits when issues with the instrumentation arose that could not be rectified remotely. Scheduled site visits included checking calibration cylinder pressures and line pump flow rates, changing of carrier gases, updating software on instruments and computers at site, emptying water decanting bowls of any liquid water, and changing line and equipment (compressor and zero-air generator) filters.

\section{Sampling and calibration}

\subsection{Sampling sequence}

Sampling sequences within the network varies between instruments. CRDS instruments within the network are continuously measuring, with RGL and TAC measuring each sampling height sequentially for 30 and $20 \mathrm{~min}$, respectively, to ensure each sampling height is measured within each hour. The CRDS at TTA measures continuously from the single $222 \mathrm{~m}$ inlet. To ensure a good stabilisation period when sampling between different heights, the first 2 min of data after the valve switches to a new sample intake is automatically flagged out. The air sampling sequence is interrupted to analyse a daily standard gas and a monthly calibration sequence, outlined in Sect. 4.2.1.

The GC-ECD, RGA and Medusa GC-MS all have a lower sampling frequency than CRDSs and therefore only sample from one inlet. Sampling frequencies within the network are $10 \mathrm{~min}$ for the GC-ECD at RGL and TAC, $20 \mathrm{~min}$ for GCFID and GC-ECD at MHD, 10 and $20 \mathrm{~min}$ for the RGA at TAC and MHD, respectively, and $65 \mathrm{~min}$ for the Medusa GCMS. Measurements alternate between ambient air and calibration gas, as outlined in Sect. 4.2.2.

\subsection{Calibration}

To guarantee the reliability and stability of measurements, automated calibrations are carried out periodically. Two separate calibration schemes are used, one for the CRDS and another for all other instruments. All tubing used for calibrant gases are 1/16 in. O.D., 0.03 in. I.D. 304 stainless steel (Supelco, Sigma-Aldrich, UK) to minimise dead volumes and wasted gas.

\subsubsection{Cavity ring-down spectrometer calibration}

CRDS instruments have two types of calibration standards, a standard of approximately ambient mole fraction and a set of calibration standards that span from below ambient up to elevated mole fractions. High-pressure aluminium tanks (Luxfer Gas Cylinders, UK) are used rather than steel to ensure long-term stability of $\mathrm{CO}_{2}$ in the calibration gases. Regulator components may also have effects on the stability of calibrations gases (Winderlich et al., 2010). Within the UK DECC network, regulators (64-2640KA411, Tescom Europe) with polychlorotrifluoroethylene (PCTFE) seals were used to prevent gas permeation. Calibrant and standard gases used in the CRDS instruments at all sites were filled and calibrated at GasLab MPI-BGC Jena and are of natural composition. $\mathrm{CO}_{2}$ is on the WMO-X2007 scale (Zhao and Tans, 2006) and $\mathrm{CH}_{4}$ is reported on the WMO-X2004A scale (Dlugokencky et al., 2005). Standard gases have a working lifetime of between 2 and 3 years, whilst calibration gases last for approximately 5 years. Once cylinders are removed from site, they are sent for recalibration.

The standard gas is measured once a day for $20 \mathrm{~min}$ to assess for linear instrumental drift, and the suite of calibration gases with varying mole fractions is measured once a month in quintuplicate to assess for instrument non-linearity and non-linear drift. The first 5 min of standard and calibration data and the first entire suite of calibration runs are removed to compensate for variability caused by regulator and line flushing. Table 6 details the standard and calibrant $\mathrm{CO}_{2}$ and $\mathrm{CH}_{4}$ mole fractions currently used at RGL, TAC, and TTA. Linear interpolation between each daily standard gas analysis is used to remove instrumental drift and is performed automatically by GCWerks (see Sect. 5.1).

Instrument non-linearity is assessed on a monthly basis by manually viewing the curve of the calibration gases and adjusted accordingly if there is a difference between the previous and current curve coefficients. Instrument nonlinearity is also reassessed after changes in instrumental soft- and hardware. Despite other studies showing CRDSs to be linear (Yver Kwok et al., 2015; Hazan et al., 2016) over the concentration ranges used in the network, all instruments were found to have a small non-linear response (example shown in Fig. 4). Therefore, a secondorder non-linear curve is fit to the data and implemented in GCWerks manually (see Sect. 5.1). There is a possi- 
Table 6. Cavity ring-down spectrometry calibrant (cal) and standard gas mole fractions for $\mathrm{CO}_{2}\left(\mu \mathrm{mol} \mathrm{mol}{ }^{-1}\right)$ and $\mathrm{CH}_{4}\left(\mathrm{nmol} \mathrm{mol}{ }^{-1}\right)$ assigned by GasLab at MPI-BGC Jena for the UK DECC network.

\begin{tabular}{|c|c|c|c|c|}
\hline \multirow[t]{2}{*}{ Species } & \multirow[t]{2}{*}{ Gas } & \multicolumn{3}{|c|}{ Site } \\
\hline & & Tacolneston (TAC) & Ridge Hill (RGL) & Angus (TTA) \\
\hline \multirow{5}{*}{$\begin{array}{l}\mathrm{CO}_{2} \\
(\mu \mathrm{mol} \mathrm{mol}-1) \\
\text { WMO-X2007 }\end{array}$} & Standard & 386.70 & 385.44 & 401.29 \\
\hline & Cal 1 & 338.85 & 338.52 & 346.93 \\
\hline & Cal 2 & 380.23 & 380.11 & 374.75 \\
\hline & Cal 3 & 419.91 & 419.61 & 449.51 \\
\hline & Cal 4 & 469.55 & 469.22 & - \\
\hline \multirow{5}{*}{$\begin{array}{l}\mathrm{CH}_{4} \\
\left(\mathrm{nmol} \mathrm{mol}^{-1}\right) \\
\text { WMO-X2004A }\end{array}$} & Standard & 1900.1 & 1953.7 & 1947.4 \\
\hline & Cal 1 & 1598.3 & 1598.2 & 1742.9 \\
\hline & Cal 2 & 1797.3 & 17989.8 & 1851.5 \\
\hline & Cal 3 & 1994.5 & 1992.0 & 2145.0 \\
\hline & Cal 4 & 2189.2 & 2188.7 & - \\
\hline
\end{tabular}

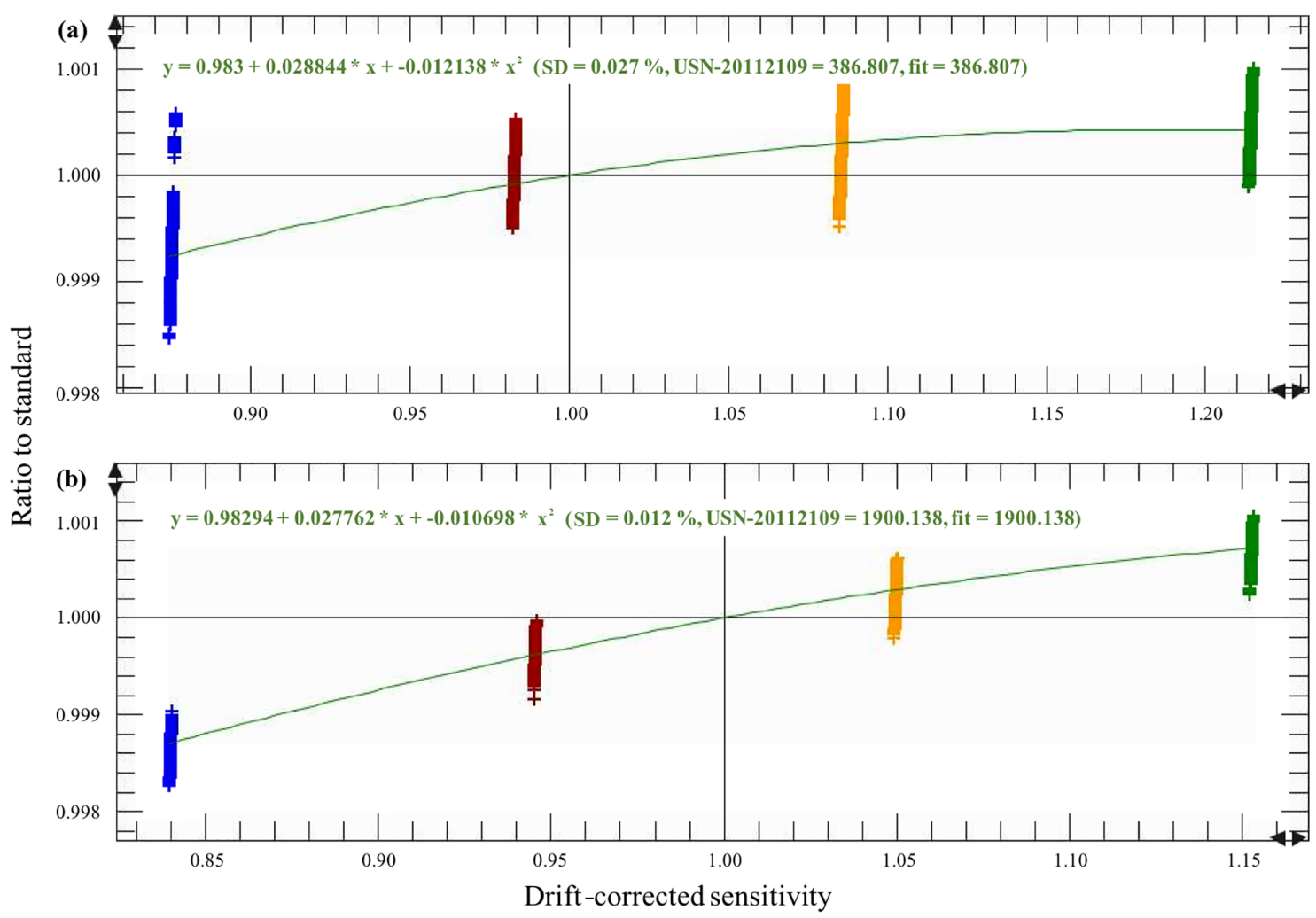

Figure 4. An example of a non-linear fit used for (a) $\mathrm{CO}_{2}$ and (b) $\mathrm{CH}_{4}$ at TAC from 2 April 2012 to 1 October 2015. Curve coefficients are shown within the plots, along with the standard used (USN-20112109), the assigned values and the adjusted values (fit $=*$ values shown in the plot). Drift-corrected sensitivity is a function of the measured cylinder dry mole fraction divided by its assigned value, over the measured standard dry mole fraction divided by the assigned/adjusted standard value, as outlined in Eq. (2).

bility that this is an artefact from the calibration cylinders; however, the non-linearity effect has also been seen when NOAA (National Oceanic and Atmospheric Administration) cylinders have been used to calibrate instruments. There is a small difference (median $\pm \mathrm{SD}$ ) between data corrected only for the linear instrumental drift and the non-linear corrected data $(-0.012 \pm 0.007,-0.002 \pm 0.01$ and $0.07 \pm 0.03 \mu \mathrm{mol} \mathrm{mol}^{-1} \mathrm{CO}_{2}$ for RGL, TTA and TAC, respectively, and a $-0.002 \pm 0.001,-0.17 \pm 0.28$ and $0.19 \pm 0.3 \mathrm{nmol} \mathrm{mol}^{-1}$ - or parts per billion, $\mathrm{ppb} \mathrm{CH}_{4}$ ).

The long-term repeatability of daily standard measurements (standard deviation, $1 \sigma$, from January 2012 to Septem- 
ber 2015) on CRDS instruments within the UK DECC network of $<0.03 \mu \mathrm{mol} \mathrm{mol}^{-1}$, and $<0.3 \mathrm{nmol} \mathrm{mol}^{-1}$ for $\mathrm{CO}_{2}$ and $\mathrm{CH}_{4}$, respectively. Short-term precision $(1 \sigma$ of $1 \mathrm{~min}$ means) was $<0.05 \mu \mathrm{mol} \mathrm{mol}^{-1}$ and $<0.3 \mathrm{nmol} \mathrm{mol}^{-1}$.

\subsubsection{Gas chromatograph calibration}

The MHD GC-ECD, GC-FID, RGA, and Medusa GC-MS instruments and the TAC Medusa GC-MS are calibrated using tertiary standards. Working standards (also known as quaternary standards) are used to calibrate the Medusa GCMS systems within the network and the GC-ECD and RGA at TAC and RGL. Tertiary and quaternary standards are prepared by compressing background ambient air into 34 L electropolished stainless steel cylinders (Essex Cryogenics, Missouri, USA) using a modified oil-free compressor (SA-3, RIX California, USA). Tertiary standards are filled at La Jolla, California, USA, and calibrated at Scripps Institution of Oceanography (SIO) against their primary calibration scales via secondary working standards before being sent to MHD or TAC. Tertiary standards are also recalibrated on return from site to assess each standard for sample stability over its working lifetime. Quaternary standards are filled at MHD and are calibrated/re-calibrated against the SIO-calibrated tertiary standards at MHD on the GC-ECD and RGA before and after use at the tall towers. Mole fractions within the tertiary and quaternary standards are close to ambient background air sample values, minimising possible sample matrix non-linearities.

The quaternary standards are used to bracket air measurements on the GC-ECD, GC-FID, RGA and Medusa GC-MS. Tertiary standards are used to bracket air measurements on the MHD GC-ECD/FID/RGA. In addition, for the Medusa GC-MS, tertiary standards are analysed weekly and are used to calibrate the quaternary standards over the course of their use in the field. Quaternary standards last for two months to two years, depending on which instrument they are being used to calibrate, and tertiary standards last approximately eight months to two years. Studies have shown that no significant drift of species contained in these standards occur over this time period (Hall et al., 2007, 2011). Calibration scales vary depending on the gas species, with $\mathrm{N}_{2} \mathrm{O}$ on SIO-98, $\mathrm{SF}_{6}$ on SIO-05, $\mathrm{CH}_{4}$ on Tohoku University, $\mathrm{H}_{2}$ on MPI-2009, and $\mathrm{CO}$ on the CSIRO04 calibration scales. A concentration difference of $1.01 \pm 4.14 \mathrm{nmol} \mathrm{mol}^{-1} \mathrm{CH}_{4}$ between the WMOx2004A and Tohoku University scales has been observed at MHD based on NOAA Earth System Research Laboratory Global GHG Reference Network flask sampling and in situ measurements (Paul B. Krummel, personal communication, 2018).

Repeatability of $20 \mathrm{~min}$ injections of tertiary/quaternary standards $(1 \sigma)$ between January 2012 and September 2015 was $<2.8 \mathrm{nmol} \mathrm{mol}^{-1}$ for GC-FID measurements of $\mathrm{CH}_{4}$ (only at MHD), $<0.4 \mathrm{nmol} \mathrm{mol}^{-1}$ for $\mathrm{N}_{2} \mathrm{O}$ (GC-ECD), $<0.07 \mathrm{pmol} \mathrm{mol}^{-1}$ for GC-ECD measurements of $\mathrm{SF}_{6}$ and
$<0.34 \mathrm{pmol} \mathrm{mol}^{-1}$ for Medusa GC-MS SF 6 measurements, $<2 \mathrm{nmol} \mathrm{mol}^{-1}$ for $\mathrm{CO}(\mathrm{RGA})$ and $<3 \mathrm{nmol} \mathrm{mol}^{-1}$ for $\mathrm{H}_{2}$ (RGA).

Due to the non-linear response of the GC-ECD to $\mathrm{N}_{2} \mathrm{O}$, non-linearity testing was carried out approximately yearly in the field. Non-linearity testing was undertaken using a high mole fraction reference gas $\left(20 \mu \mathrm{mol} \mathrm{mol}^{-1} \mathrm{~N}_{2} \mathrm{O}\right.$ and $1 \mathrm{nmol} \mathrm{mol}^{-1} \mathrm{SF}_{6}$ gas mix, BOC, Surrey, UK), which was dynamically diluted with zero air (Zero Air Plus, Air Liquide, Cheshire, UK) to the range of atmospheric mole fractions $\left(\mathrm{N}_{2} \mathrm{O}: 240-400 \mathrm{nmol} \mathrm{mol}^{-1} ; \mathrm{SF}_{6}\right.$ : 6-14 $\left.\mathrm{pmol} \mathrm{mol}^{-1}\right)$ using a custom-made dynamic dilution unit made up of two RED-y mass flow controllers (GSC-A3TA-BB21, $100 \mathrm{~mL} \mathrm{~min}^{-1}$; GSC-A4TA-BB22, $200 \mathrm{~mL} \mathrm{~min}^{-1}$; Vögtlin Instruments AG, Switzerland). During the non-linearity test, the zero-air cylinder was analysed to check for traces of $\mathrm{N}_{2} \mathrm{O}$ and $\mathrm{SF}_{6}$. Cylinders with detectable contamination were not used. Results were used to create a second-order nonlinearity curve and a correction was implemented in GCWerks (see Sect. 5.2).

\section{Data processing}

GCWerks is used to process all of the CRDS, RGA and GC data. Raw measurement data and ancillary parameters stored on the local site computers are processed on site in near-real time (NRT) for calibration and $\mathrm{H}_{2} \mathrm{O}$ corrections. Processing of data on site has the added advantage of aiding troubleshooting of instruments for site technicians.

Raw and processed data are mirrored daily from the local site computer to data processing servers at the UoB or at the University of East Anglia (UEA) for TAC GC-ECD/RGA and Medusa GC-MS. Post-processed UEA data are also mirrored to the UoB servers for archiving. All raw and processed data (calibrated and $\mathrm{H}_{2} \mathrm{O}$ corrected; Sect. 5.1-5.2) are subjected to QA/QC (Sect. 5.3), ensuring comparison with physical instrument parameters, such as CRDS cavity temperature and pressure, or flow rates, to check for spurious data. Data corrections outlined in Sect. 5.1-5.2 are investigated and implemented on the processing servers and then mirrored back to the sites.

\subsection{Algorithms for calculating $\mathrm{CO}_{2}$ and $\mathrm{CH}_{4}$}

Raw CRDS data and ancillary parameters are acquired by GCWerks and are stored in binary stripcharts. These stripcharts contain all relevant data from the CRDS, i.e. wet and dry mole fractions, $\mathrm{H}_{2} \mathrm{O}$ mole fractions, cavity temperature and pressure. Metadata stored within log files in GCWerks describe each sample type (air, std, cal), inlet height, the quantity of data to be rejected and data averaging frequencies for each Valco valve port within the sample selection system. Data within the network are averaged over 1, 5, 20 and $60 \mathrm{~min}$ intervals. The first $2 \mathrm{~min}$ of air and $5 \mathrm{~min}$ of stan- 
Table 7. Parameters used in GCWerks for automatic CRDS data filtering until September 2015.

\begin{tabular}{ll}
\hline Filter & Threshold \\
\hline Cavity pressure (Torr) & $<139.9,>140.1$ \\
Cavity temperature $\left({ }^{\circ} \mathrm{C}\right)$ & $<44.98,>45.02$ \\
Water value $(\%)$ & 6 \\
Cycle time (s) & $>8$ \\
Standard deviation & a,b \\
\hline
\end{tabular}

${ }^{a}$ For measured compounds ( $\mathrm{pmol} / \mathrm{nmol} / \mathrm{Mmol} \mathrm{mol}^{-1}$ ) and water $(\%) .{ }^{b}$ Points outside of the set number of standard deviations are filtered recursively until all points are lower than the set parameter. For air data, a 2 min moving window is used to filter out extreme outliers. The moving windows overlap by $1 \mathrm{~min}$.

dard/calibration data after the Valco selector valve switches within the sample system are automatically rejected to allow for stabilisation time and the tubing to condition with the new sample.

A number of data filters are automatically applied to the CRDS data before 1, 5, 10, 20 and 60 min means are calculated. These filters remove, for instance, cavity pressure and temperature out of normal operating range, high $\mathrm{H}_{2} \mathrm{O}$ levels, slow cycle times and standard deviations in sample values that are too great (Table 7). Parameterisation of filters is generic for the type of analyser but can be user defined within GCWerks. For each single data point, these filter parameter values are verified and the data point discarded from the final dataset if not.

CRDS measurements are then corrected for linear instrumental drift and instrumental response over a span of different mole fractions, referred to here as non-linearity. As in Verhulst et al. (2017), linear instrumental drift, monitored by repeated measurements of a calibrated standard gas measured daily for $20 \mathrm{~min}$, is corrected for by the ratio of a measurement to the linear interpolation between bracketing standard measurements, as outlined in Eq. (1). However, unlike in Verhulst et al. (2017), instrumental non-linearity is assessed and implemented using a function of the sample/standard ratio, outlined in Eq. (2). A second-order function can then be fitted to the data to provide a non-linearity correction in Eq. (1).

$C_{\text {samp }}=\frac{\left(\frac{R_{\text {samp }}}{R_{\text {std }}} \cdot C_{\text {std }}\right)}{\text { NonLin }}$,

NonLin $=f\left(\frac{R_{\mathrm{cal}}}{R_{\mathrm{std}}}\right)=\frac{\left[\frac{R_{\mathrm{cal}}}{C_{\mathrm{cal}}}\right]}{\left[\frac{R_{\mathrm{std}}}{C_{\mathrm{std}}}\right]}$,

where $C_{\text {samp }}$ is the calibrated $\mathrm{CO}_{2}$ or $\mathrm{CH}_{4}$ mole fraction, and $R_{\text {samp }}$ and $R_{\text {cal }}$ are the sample and calibrant raw dry-air mole fraction from the CRDS, respectively, $R_{\text {std }}$ is the linear interpolation between the raw dry-air mole fraction of the two bracketing standards, $C_{\text {std }}$ and $C_{\text {cal }}$ are the calibrated mole fraction assigned at GasLab MPI-BGC Jena, and NonLin is the non-linearity correction coefficient assigned by the user from the second-order fit of calibration data.

\subsection{Algorithms for calculating $\mathrm{N}_{2} \mathrm{O}, \mathrm{SF}_{6}, \mathrm{CH}_{4}$ (from GC-FID), $\mathrm{CO}$ and $\mathrm{H}_{2}$}

GC data and ancillary parameters are acquired by GCWerks and stored in chromatograms and stripcharts, as well as being displayed in real time. Temperature (ambient and sample selection module), loop flow rates and pressures at the time of sample injection onto the columns are also stored in a sample $\log$ file with the corresponding date and time.

User defined integration parameters allow for automatic integration of peaks. Chromatograms can be reprocessed for selected periods when peak integration parameters need to be altered due to changes in baseline and retention times. Integrated peak heights and areas are stored and used along with pressure and temperature data stored in the sample log file to calculate mixing ratios.

$\mathrm{N}_{2} \mathrm{O}, \mathrm{SF}_{6}, \mathrm{CH}_{4}, \mathrm{CO}$ and $\mathrm{H}_{2}$ are calibrated for linear instrumental drift and non-linearity in a similar way to measurements from the CRDS instrument. A variation of Eq. (1) is used to calibrate data for linear instrumental drift using sample integrated height $\left(\mathrm{SF}_{6}, \mathrm{CH}_{4}, \mathrm{CO}\right.$ and $\left.\mathrm{H}_{2}\right)$ or area $\left(\mathrm{N}_{2} \mathrm{O}\right.$; Eq. 3). The non-linearity fit is defined using the dynamic dilution of a high concentration cylinder, as described in Sect. 4.2.2 and implemented using Eq. (4).

$$
\begin{aligned}
& C_{\text {samp }}=\frac{\mathrm{RL} \cdot C_{\text {std }}}{\text { NonLin }}, \\
& \mathrm{RL}=\frac{R_{\text {samp }}}{R_{\text {std }}} \cdot \frac{\frac{P_{\text {samp }} \cdot V}{R \cdot T_{\text {samp }}}}{\frac{P_{\text {std }} \cdot V}{R \cdot T_{\text {std }}}},
\end{aligned}
$$

where $C_{\text {samp }}$ is the calibrated $\mathrm{N}_{2} \mathrm{O}, \mathrm{SF}_{6}, \mathrm{CO}$ and $\mathrm{H}_{2}$ mole fraction; RL is the sample/standard ratio; $R_{\text {samp }}$ is the sample raw dry mole fraction; $R_{\text {std }}$ is the linear interpolation between the raw dry-air mole fraction of the two bracketing standards; $C_{\text {std }}$ is the calibrated standard mole fraction; NonLin is the non-linearity correction coefficient assigned by the user from the second-order fit of calibration data; $P_{\text {samp }}$ and $P_{\text {std }}$ are the sample and standard loop pressures, respectively, at the time of sample injection; $T_{\text {samp }}$ and $T_{\text {std }}$ are the sample and standard gas temperatures, respectively, at the time of injection; $V$ is the loop volume; and $R$ is a gas constant.

\subsection{Final data processing}

In the first phase, chromatograms and stripcharts are reviewed daily, on a site-by-site basis to check for good integration and systematic biases not detected by automatic data processing routines. Filtered data are also reviewed in the stripcharts, shown in conjunction with the unfiltered data, to ensure good filter parameterisation, ensure non-spurious data are not unnecessarily filtered out and help diagnose in- 


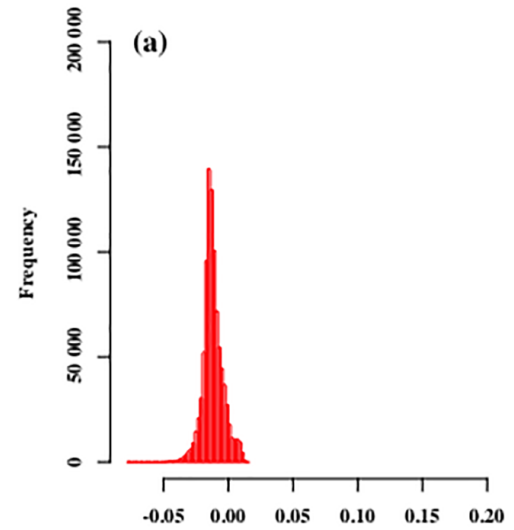

$\Delta \mathrm{CO}_{2}$ (linear-nonlinear corrected; $\mu \mathrm{mol} \mathrm{mol}^{-1}$ )

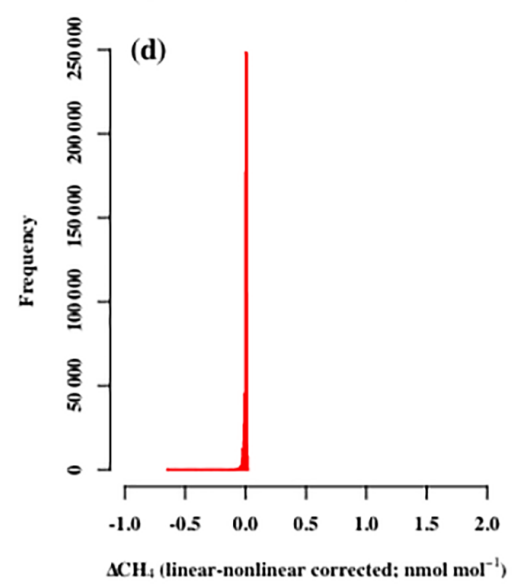

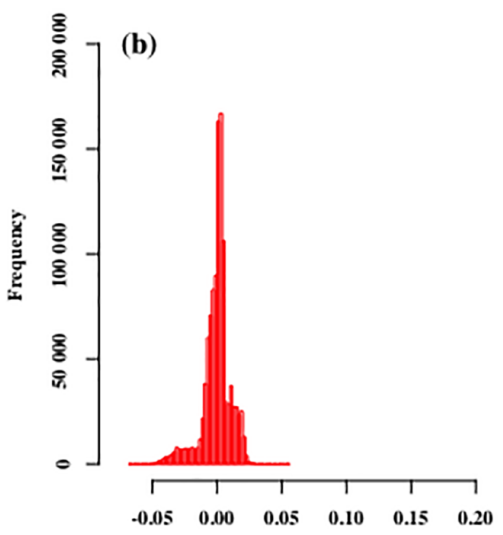
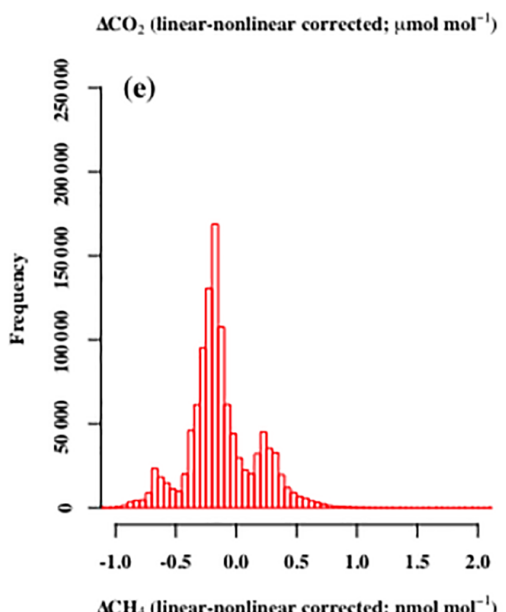
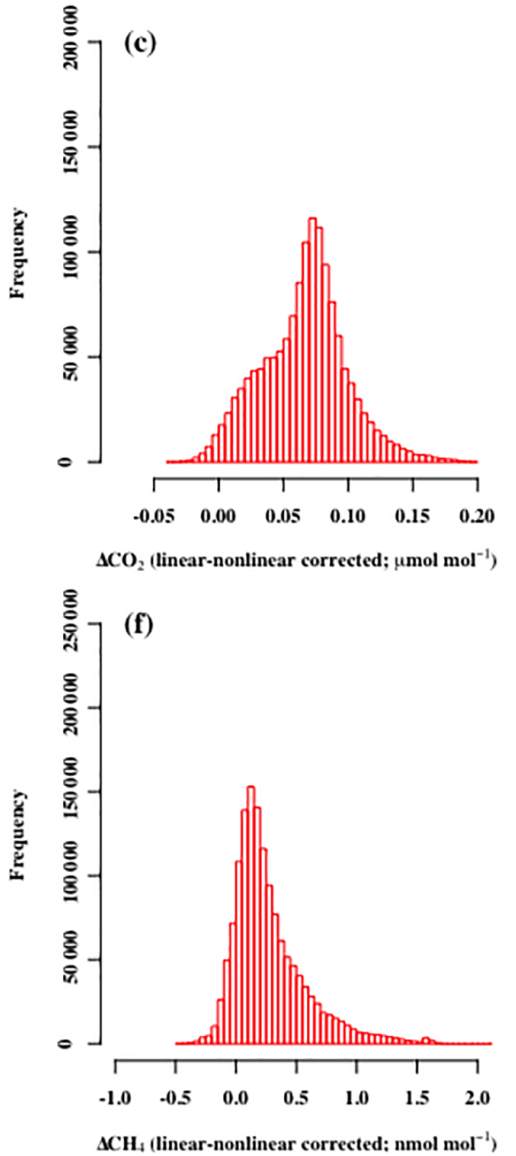

Figure 5. Histograms of the difference between linear corrected data (Eq. 1) and non-linear corrected data (Eq. 2) for CO 2 at (a) RGL, (b) TTA, and (c) TAC, and $\mathrm{CH}_{4}$ at (d) RGL, (e) TTA, and (f) TAC.

strumental issues. Data and ancillary measurements are reviewed in parallel to help observe potential errors and diagnose issues within the data. Instrument precision is reviewed by monitoring the standard gas concentrations for anomalies. To further investigate data issues, 1, 5, 20 and 60 min mean (CRDS) or discrete (GC-ECD/FID/RGA and Medusa GCMS) air data can also be plotted against instrumental and ancillary parameters. Spurious data are manually flagged and a justification for the flagging of data is given and logged.

In the second phase, data from the entire network are imported and reviewed simultaneously in GCcompare, custombuilt data visualisation software for time series data from multiple sites. Flagged GCWerks time series data from the network are overlain to compare sites with the background station (MHD) and to look for differences between sites for each compound measured in the network. Potential issues not previously noted are investigated using ancillary and instrumental parameters, which are also imported into GCcompare, as well as air-history maps produced on an hourly basis using the Numerical Atmospheric dispersion Modelling Environment (NAME) Lagrangian dispersion model outlined in Manning et al. (2011).

\subsection{Troubleshooting data issues}

Collection, storage and visualisation of ancillary data in GCWerks in parallel with mole fraction data have made troubleshooting data issues easier. When potential issues are observed in the time series data, site operators check the ancillary data recorded to try and help identify potential issues.

Within the network, one of the greatest issues observed so far is laboratory temperature stability, which can affect the performance of the instrumentation. At sites with and without air conditioning, rapid fluctuations in temperature have resulted in poorer precision in the data, as observed in the ambient temperature data recorded on the GC-ECDs. In laboratories with air conditioning (TAC and MHD), economy modes have often been used to reduce the frequency of the unit being switched on and off, thus smoothing the temperature swings in the laboratory. At RGL, the ventilation system is set to being either constantly on in the summer or off during the winter months to smooth temperature fluctuations in the laboratory. A number of other issues observed within the network are shown in Table 8. 
Table 8. Troubleshooting data issues observed in the UK DECC network from it starting in 2012 to September 2015.

\begin{tabular}{|c|c|c|}
\hline Problem & Observation & Comment \\
\hline $\begin{array}{l}\text { Increasing laboratory } \\
\text { temperature at TAC }\end{array}$ & $\begin{array}{l}\text { Automatic email triggered } \\
\text { when maximum ambi- } \\
\text { ent temperature setpoint } \\
\text { reached }\end{array}$ & $\begin{array}{l}\text { Automatic shutdown of Medusa GC-MS and email sent to site oper- } \\
\text { ators, who logged on and shutdown instruments to reduce heat load } \\
\text { into laboratory and protect instruments. }\end{array}$ \\
\hline Line filter blockage & $\begin{array}{l}\text { Decreasing outlet valve } \\
\text { value in CRDS time series }\end{array}$ & $\begin{array}{l}\text { Change relative to other sample inlet values. Once detected, site oper- } \\
\text { ator can replace the inlet filter. }\end{array}$ \\
\hline Line pump failure & $\begin{array}{l}\text { Increasing outlet valve } \\
\text { value in CRDS time series }\end{array}$ & $\begin{array}{l}\text { A steadily increasing outlet valve value can indicate a tear forming } \\
\text { in the diaphragm of the line pumps. Eventually there will be a step } \\
\text { change in the valve value when the diaphragm completely fails. Site } \\
\text { operators can log on remotely to remove the affected inlet line from } \\
\text { the sampling sequence. }\end{array}$ \\
\hline Router problems & No data transfer & $\begin{array}{l}\text { A number of routers have failed at sites due to the constant use. Usu- } \\
\text { ally if no access to site can be gained, a site operator will make an } \\
\text { emergency visit. }\end{array}$ \\
\hline Cylinders vented & $\begin{array}{l}\text { Spurious data for cylinder } \\
\text { and if on CRDS, lower than } \\
\text { normal outlet valve value }\end{array}$ & $\begin{array}{l}\text { Cylinders have vented during the time period reported. Safe positions } \\
\text { have been introduced so that when the instrument stops, the valve in } \\
\text { the sample module goes to the safe position. If mismatches in valve } \\
\text { positions occur, site operators are warned by automatically generated } \\
\text { emails. }\end{array}$ \\
\hline $\begin{array}{l}\text { Contaminated carrier } \\
\text { gas cylinder }\end{array}$ & $\begin{array}{l}\text { Increasing baseline, smaller } \\
\text { peaks or increasing blank } \\
\text { concentrations }\end{array}$ & $\begin{array}{l}\text { Test all carrier gases for contamination on instruments as an unknown } \\
\text { before connection to any instrument. }\end{array}$ \\
\hline
\end{tabular}

\section{Results}

Measurements of GHGs from the UK DECC network are presented from January 2012 through to September 2015 (Figs. 6 to 8; see Sect. 2 for details of start dates of data acquisition). Results shown in this paper are limited to qualitative analyses of the most prominent features of the data; utilisation of this large and comprehensive dataset to its full potential lies in the use of high-resolution inverse atmospheric transport models (Manning et al., 2011; Vermeulen et al., 2011; Ganesan et al., 2015). All $\mathrm{CO}_{2}$ and $\mathrm{CH}_{4}$ data are publicly available as hourly means, whilst $\mathrm{N}_{2} \mathrm{O}, \mathrm{SF}_{6}$, $\mathrm{CO}$ and $\mathrm{H}_{2}$ are available as discrete samples, at EBAS, as database infrastructure operated by the Norwegian Institute for Air Research (http://ebas.nilu.no/) and the World Data Centre for Greenhouse Gases (http://ds.data.jma.go.jp/gmd/ wdcgg/). All MHD data, except CO mole fractions, are available from the Carbon Dioxide Information Analysis Center (CDIAC) at https://doi.org/10.3334/CDIAC/atg.db1001 (Prinn et al., 2017).

\subsection{Seasonal cycles}

$\mathrm{CO}_{2}$ shows the most marked seasonal cycle of all the GHGs measured in the UK DECC network, due to its major biogenic uptake via photosynthesis and production from respiration, as well as anthropogenic sources. The approximate amplitude for mid-latitude Northern Hemisphere seasonal cycle is $15 \mu \mathrm{mol} \mathrm{mol}^{-1}$ and has an upwards trend. Figure $6 \mathrm{a}$ shows $\mathrm{CO}_{2}$ maxima in January/February and minima in $\mathrm{Au}-$ gust. Sites show a $\mathrm{CO}_{2}$ signal that varies in a "noise" band of approximately $20 \mu \mathrm{mol} \mathrm{mol}^{-1}(\sim 5 \%)$, alongside a strong seasonal cycle. Large differences between the sites can also be observed from $\mathrm{CO}_{2}$ data in Fig. 6a. TTA shows the lowest frequency and magnitude of above baseline events. This is thought to be a combination of the tower inlet height, which is at $222 \mathrm{~m}$ a.g.l. compared to lower inlets at RGL (45/90 m a.g.l.) and TAC (54/100/185 m a.g.l.), and the location of TTA in the north of the UK in a much more sparsely populated region than the other sites. TAC $\mathrm{CO}_{2}$ mole fractions have greater excursions from baseline compared with the other sites due to its eastern location, downstream of the predominant south-westerly wind direction, and location near to a number of large sources.

$\mathrm{CH}_{4}$ also shows seasonal variation (see Fig. 6b) with a winter maxima and a summer minima, driven by greater oxidation by hydroxyl radicals in strong sunlight and greater uptake from the troposphere by methanogenic bacteria in soils (Dlugokencky et al., 2011). The approximate amplitude for mid-latitude Northern Hemisphere seasonal cycle at MHD is $21 \mathrm{nmol} \mathrm{mol}^{-1}$ and has an upwards trend. Differences between site baseline (unpolluted) mole fractions can be observed in Fig. 6b. The relative variability in $\mathrm{CH}_{4}$ atmospheric signal within the UK DECC network varies roughly between 1800 and $2300 \mathrm{nmol} \mathrm{mol}^{-1}$. MHD and TTA generally agree well over the observation period and have the lowest frequency and magnitude of pollution events. This is thought to be due to fewer pollution sources within the prevailing wind 

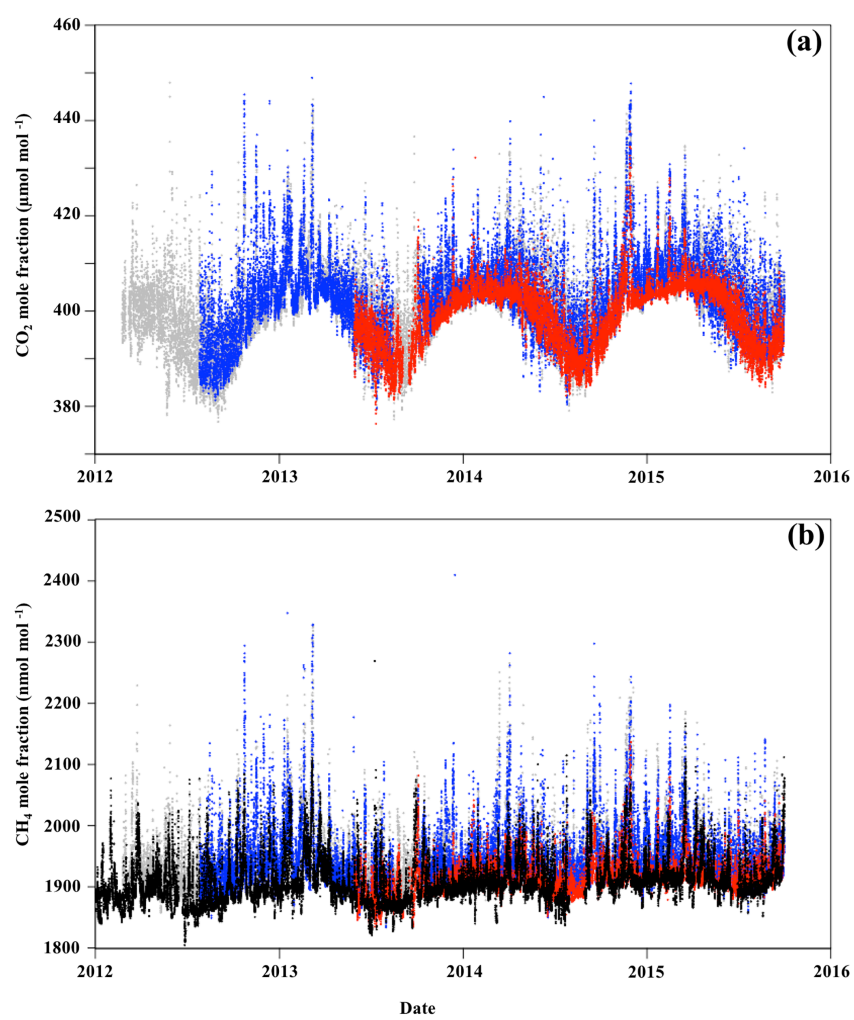

Figure 6. Time series of (a) $\mathrm{CO}_{2}$ and (b) $\mathrm{CH}_{4}$ mole fractions at MHD (black; $10 \mathrm{~m}$ inlet) RGL (grey; $90 \mathrm{~m}$ inlet), TTA (red; $222 \mathrm{~m}$ inlet) and TAC (blue; $100 \mathrm{~m}$ inlet) from 1 January 2012 to 30 September 2015. Results shown are hourly averages. $\mathrm{CO}_{2}$ results shown are in $\mu \mathrm{mol} \mathrm{mol}{ }^{-1}$ and are on the WMO-X2007 scale. $\mathrm{CH}_{4}$ results are shown in $\mathrm{nmol} \mathrm{mol}^{-1}$ and are on the WMO-X2004A scale.

direction at both MHD and TTA. As per $\mathrm{CO}_{2}$, TAC has the greatest excursions in $\mathrm{CH}_{4}$ mole fraction compared with the other sites in the network due to its location downwind of major urban areas such as London and Birmingham in prevailing wind directions.

A seasonal cycle is also observed in $\mathrm{N}_{2} \mathrm{O}$ mole fractions (see Fig. 7a); however, this seasonality is less well defined than for $\mathrm{CO}_{2}$, especially in 2014. There is an approximate $0.8 \mathrm{nmol} \mathrm{mol}^{-1}$ amplitude in the Northern Hemisphere midlatitude seasonal trend at MHD. Summer minima in $\mathrm{N}_{2} \mathrm{O}$ are thought to be caused by the descent of stratospheric air bringing $\mathrm{N}_{2} \mathrm{O}$-depleted air into the troposphere across the polar tropopause (Nevison et al., 2011). The atmospheric signal has an upward trend and varies between 322 and $338 \mathrm{nmol} \mathrm{mol}^{-1}$. Like $\mathrm{CO}_{2}$ and $\mathrm{CH}_{4}$, magnitude and frequency of $\mathrm{N}_{2} \mathrm{O}$ pollution events are greater at RGL and TAC than MHD. This is thought to be due to the surrounding land being used predominately for agriculture and fertiliser application causing nitrification and denitrification to occur.

Tropospheric $\mathrm{SF}_{6}$ mole fractions do not show a seasonal cycle but a clear increase over time (see Fig. 7b). The at-
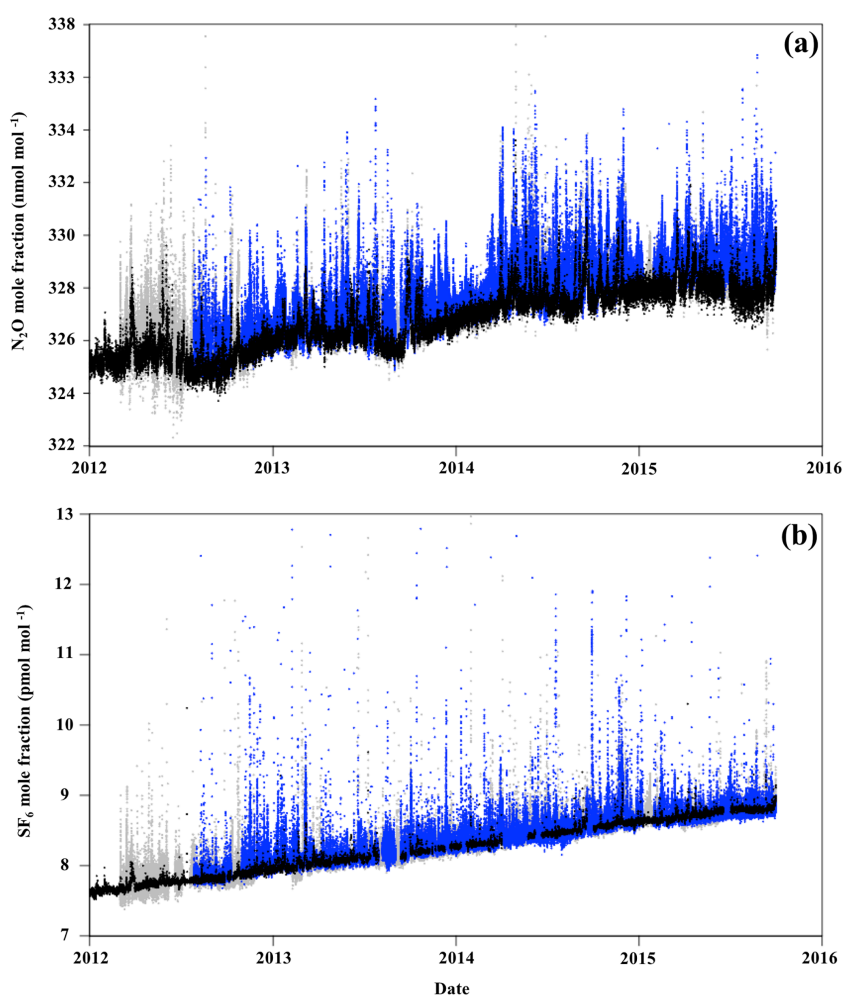

Figure 7. Time series of (a) $\mathrm{N}_{2} \mathrm{O}$ and (b) $\mathrm{SF}_{6}$ mole fractions at MHD (black; $10 \mathrm{~m}$ inlet), RGL (grey; $90 \mathrm{~m}$ inlet) and TAC (blue; $100 \mathrm{~m}$ inlet) from 1 January 2012 to 30 September 2015. All results shown are hourly averages. $\mathrm{N}_{2} \mathrm{O}$ results are shown in nmol mol ${ }^{-1}$ and are on the SIO-98 scale, whilst $\mathrm{SF}_{6}$ results are shown in pmol mol${ }^{-1}$ and are on SIO-05 scale. $\mathrm{SF}_{6}$ results from MHD are made using the Medusa GC-MS.

mospheric variability within the network is between 7.5 and $13 \mathrm{pmol} \mathrm{mol}^{-1}$. The magnitude and frequency of $\mathrm{SF}_{6}$ pollution events at RGL and TAC are greater than at MHD as emissions are predominantly from anthropogenic sources. Natural sources of $\mathrm{SF}_{6}$ are considered to be so low they can be ignored (Levin et al., 2010).

A seasonal cycle is also observed in $\mathrm{CO}$ and $\mathrm{H}_{2}$ at MHD and TAC (Fig. 8). There is an approximate 37 and $36 \mathrm{nmol} \mathrm{mol}^{-1}$, for $\mathrm{CO}$ and $\mathrm{H}_{2}$, respectively, Northern Hemisphere mid-latitude seasonal trend. $\mathrm{CO}$ has winter maxima and summer minima, driven predominantly by anthropogenic emissions and the strength of the summertime $\mathrm{OH}$ sink (Grant et al., 2010b; Satar et al., 2016). $\mathrm{H}_{2}$ has delayed spring maxima and autumn minima due to maximum summertime loss by $\mathrm{OH}$ oxidation and greatest rates of soil uptake in the summer and early autumn, when soils are driest (Grant et al., 2010b).

\subsection{Diurnal cycles and vertical gradients}

In principal, measurements of GHGs at different heights at a station allow observations of sources and sinks from differ- 

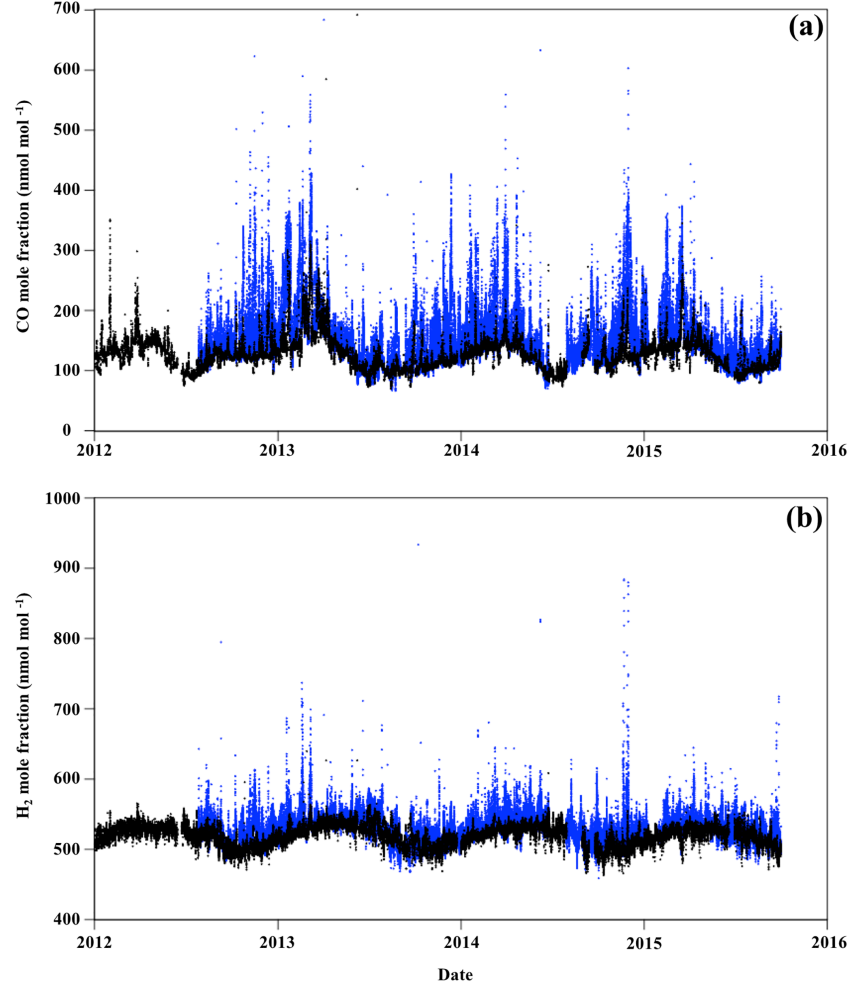

Figure 8. Time series of (a) $\mathrm{CO}$ and (b) $\mathrm{H}_{2}$ mole fractions at MHD (black; $10 \mathrm{~m}$ inlet) and TAC (blue; $100 \mathrm{~m}$ inlet) from 1 January 2012 to 30 September 2015 . All results shown are hourly averages, shown in nmol mol ${ }^{-1}$ and are on CSIRO04 and MPI-2009 scales for CO and $\mathrm{H}_{2}$, respectively.

ent spatial footprints (Vermeulen et al., 2011). The average diurnal profiles for $\mathrm{CO}_{2}$ and $\mathrm{CH}_{4}$ at RGL and TAC (Fig. 9) are from 1 January 2012 to 30 September 2015.

The greatest difference in $\mathrm{CO}_{2}$ mole fraction between the lowest and highest inlets were 3 and $8 \mu \mathrm{mol} \mathrm{mol}^{-1}$ at RGL and TAC, respectively. Daytime vertical differences were very small for all seasons $\left(<1 \mu \mathrm{mol} \mathrm{mol}^{-1}\right)$ for both TAC and RGL. Spring, summer and autumn daytime concentrations are generally lower at the lowest inlet heights for RGL and TAC due to the net biospheric $\mathrm{CO}_{2}$ uptake within the footprint area. $\mathrm{CO}_{2}$ uptake during the daytime was also observed during winter months, although this is less pronounced than other seasons and wintertime average daytime $\mathrm{CO}_{2}$ concentrations are always greater at the lowest inlet height.

Diurnal variation in $\mathrm{CH}_{4}$ shows similar patterns to $\mathrm{CO}_{2}$, with early morning maxima and early afternoon minima; however, the daytime increases in mole fraction with height as in Fig. 9a and b are not observed in $\mathrm{CH}_{4}$ (Fig. 9c and d) as mixing ratios are not dominated by biospheric photosynthesis. Average summertime $\mathrm{CH}_{4}$ concentrations are $\sim 20 \mathrm{nmol} \mathrm{mol}^{-1}$ less than other seasons due to greater oxidation by hydroxyl radicals. In winter, vertical $\mathrm{CH}_{4}$ concentration gradients are maintained throughout the day and

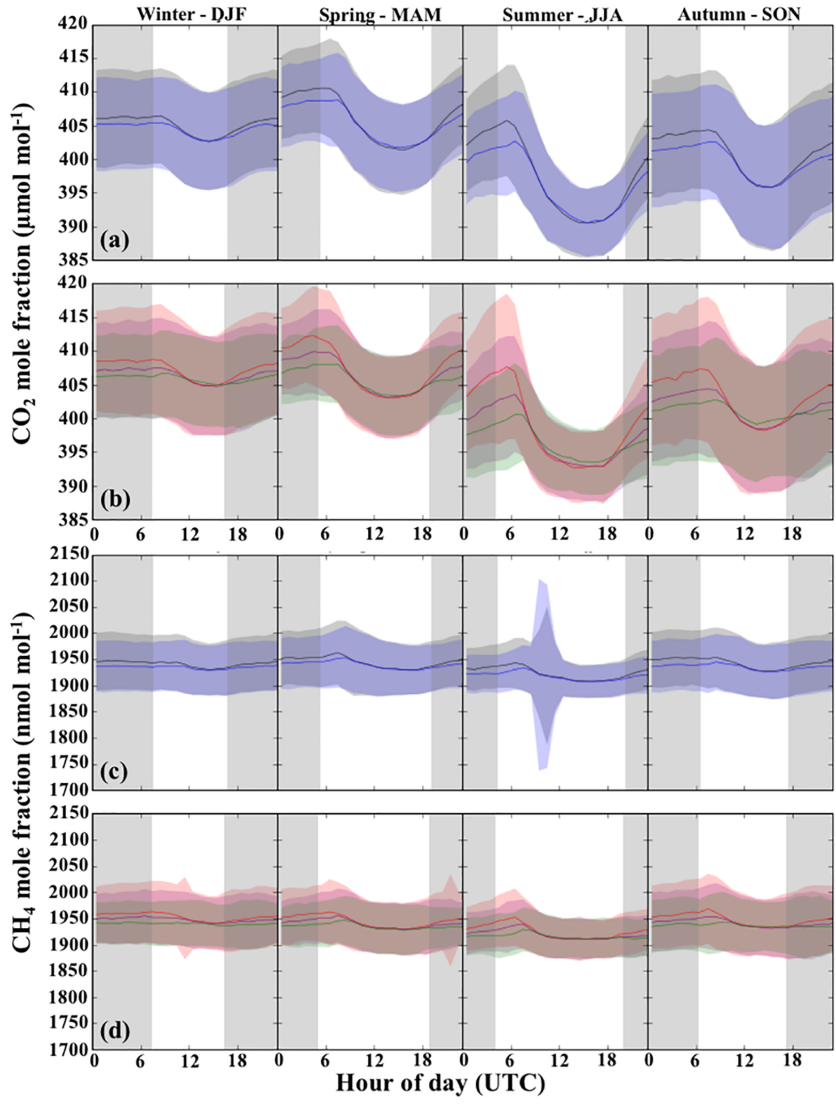

Figure 9. Overview of average diurnal concentration gradients in $\mathrm{CO}_{2}$ at (a) RGL and (b) TAC as well as $\mathrm{CH}_{4}$ at (c) RGL and (d) TAC from 23 January 2012 to 1 October 2015. Lines are the median of the entire data period and shaded areas represent the standard deviation $(1 \sigma)$. Black and blue data correspond to the 45 and $90 \mathrm{~m}$ a.g.l. inlet at RGL, respectively, and red, purple and green correspond to the 54, 100 and $185 \mathrm{~m}$ a.g.l. inlets at TAC. Shaded grey areas represent mean seasonal night-time based on the sites' latitude and longitude. Data shown are in UTC.

night due the persistence of a low planetary boundary layer during daytime. Maximum gradients between the lowest and highest inlets show variation of $\sim 10$ and $20 \mathrm{nmol} \mathrm{mol}^{-1}$ for RGL and TAC, respectively, a similar percentage difference to $\mathrm{CO}_{2}$ concentration gradients.

\subsection{Discerning pollution events}

Air history maps, showing the previous 30 days of surface influence at the station in a $1 \mathrm{~h}$ period, were produced using the Met Office NAME Lagrangian atmospheric dispersion model (Jones et al., 2007) for each of the sites within the UK DECC network in order to discern and explain pollution signals in the mole fraction measurements. Increasing mole fractions with longitude across the UK from the baseline station (MHD) are frequently seen within the data, as demonstrated in Fig. 10a on 5 December 2014. Figure 10b also 


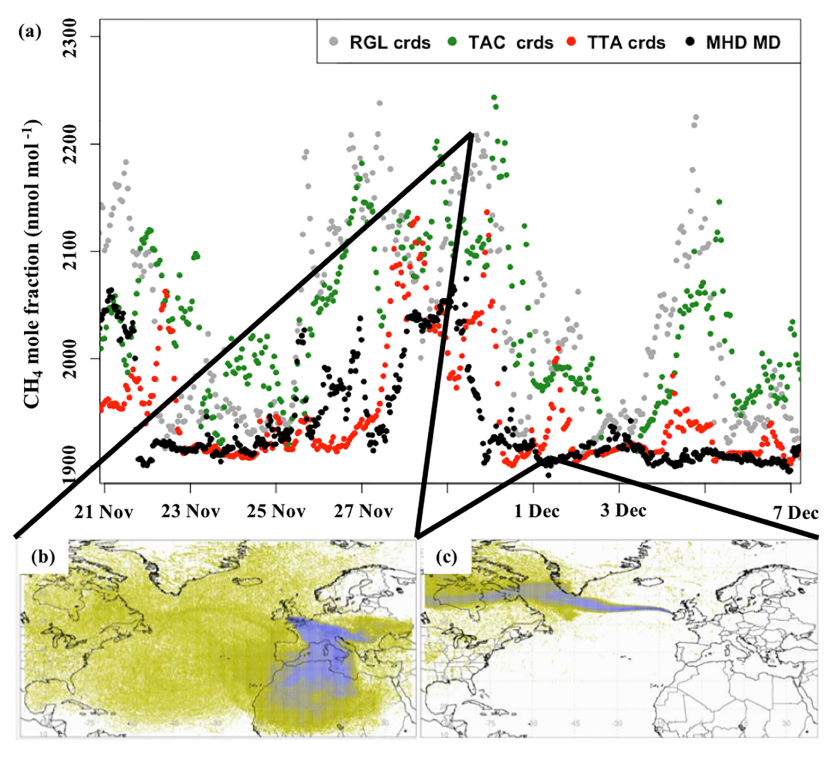

Figure 10. Examples of (a) $\mathrm{CH}_{4}$ mole fractions from 21 November to 7 December 2014 (MHD MD discrete samples, CRDS values $20 \mathrm{~min}$ averages), and $2 \mathrm{~h}$ air-history maps derived from NAME (b) for RGL, regionally polluted period, and (c) for MHD, baseline period. The air-history maps describe which surface areas $(0-40 \mathrm{~m})$ in the previous 30 days impact the observation point within a particular $2 \mathrm{~h}$ period. Black lines in (a) indicate the data point that the air-history maps in (b) and (c) correspond to.

demonstrates a regionally polluted period at RGL for $\mathrm{CH}_{4}$ on 30 November 2014, when air passed over Europe and the south of the UK before arriving at the site. Figure 10c shows an example of baseline conditions for $\mathrm{CH}_{4}$ on 1 December 2014, when air passed over the North Atlantic Ocean, resulting in low mole fractions at MHD and variation between the other UK DECC sites.

\section{Recommendations}

Many lessons have been learnt with setting up and running the UK DECC network and we have tried to summarise the main points for future stations or networks.

\subsection{Instrumentation modularity and automation}

Monitoring stations are often located in remote areas that are not easily accessible. The need for designing instrumentation that can be fully automated and controlled on site with minimal on-site human attention is extremely important. Additionally, it is crucial that the software used to control the instrumentation can be accessed remotely to make changes to sampling regimes when issues arise. As suggested by Andrews et al. (2014), modularity in the analytical systems helps simplify maintenance and repairs. We aim to have spare modules, such as line pump modules, based in the UoB laboratory that can be sent or taken to site as soon as there is a sign of an imminent problem. This is not always feasible for larger and more expensive items, such as instrument boards; however, these items do not fail as frequently as line pumps or inlet filters.

\subsection{Software}

A number of software packages are now commercially available and are able to control instruments and log data. However, there are fewer packages available that are able to control instruments, log data and visualise data rapidly. Being able to visualise all data, including ancillary data and even after the data have been post-processed, at the site has the added advantage of being able to look back through the time series for when an issue may have previously happened and then check the operations log to see how the problem was rectified. This is especially important when a number of site operators make visits.

Comprehensive measurement and logging of critical pressures, temperatures and flow rates are necessary for detecting instrumental problems. Automated alarm emails based on the data can notify site operators of failures and help to reduce instrument downtime. Prior to the alarms being integrated within the network, problems with the data and instruments went unnoticed for several days. Customisation of alarm parameters can also help to reduce false alarms.

\subsection{Calibration}

High-precision data require frequent field calibration, even for modern $\mathrm{CO}_{2}$ and $\mathrm{CH}_{4}$ spectrometers that are extremely stable. Any calibration gases used within a network should be traceable to a scale to ensure that measurements are comparable between sites. We recommend using scales that are already well defined and widely used, such as the WMO scales (WMO-GAW, 2016). There are a number of different ways to calibrate data (Andrews et al., 2014; Hazan et al., 2016; Verhulst et al., 2017); however, we recommend using a method that calibrates out short-term instrumental drift as this is not fully captured when linearly interpolating between monthly calibrations and can introduce error into data.

It is recommended to have more than the minimum number of calibration cylinders required to generate a calibration curve depending on the instrument needs; however, space and financial constraints can reduce the number of cylinders available. As a guide for CRDS instruments, we have a minimum of three calibration cylinders and one standard cylinder per analyser. We also recommend having spare standard and calibration cylinders, which can be kept off site, in case cylinders need urgently replacing following failures. Standard cylinders should be at ambient mole fractions and calibration cylinders should span the expected ambient range. Standards and calibrants should have the same matrix as the sample air and a similar isotopic composition to ambient air. 


\subsection{Carrier gas purity}

On a number of occasions, P5 and He carrier gases have been contaminated with $\mathrm{SF}_{6}$ due to being pressure-tested at the end of their inspection life cycle. We recommend testing all carrier gases as an unknown sample on instruments to double-check for contamination of gases being measured. Before testing cylinders within the network for contamination, contaminated carrier gases were connected to GCs and resulted in increasing baselines and sample signal suppression.

\section{Summary and conclusions}

The UK DECC network was established in January 2012 to monitor atmospheric GHG and ODS mole fractions and verify the UK emission inventories submitted to the UNFCCC. The network was expanded from MHD, where GHG and ODS measurements have been made since 1987, to include RGL, Herefordshire, England; TAC, Norfolk, England; and TTA, Dundee, Scotland.

We have designed a network with robust systems for unattended continuous measurement of atmospheric $\mathrm{CO}_{2}, \mathrm{CH}_{4}$, $\mathrm{N}_{2} \mathrm{O}, \mathrm{SF}_{6}, \mathrm{CO}$ and $\mathrm{H}_{2}$ mixing ratios using a suite of instruments at tall open-lattice telecommunications towers. Results from the network give good temporal coverage of atmospheric mixing ratios since January 2012. Results from the network show that all GHGs are increasing in concentration over the selected reporting period and, except for $\mathrm{SF}_{6}$, exhibit seasonal trends. Discrete sample and hourly mean data are freely available from EBAS at http://ebas.nilu.no/ for GC-ECD/RGA and CRDS, respectively, for all three UK sites. All MHD data, except CO mole fractions, are available from CDIAC (Prinn et al., 2017). The instrumentation, software used and post-processing methods described in this paper are one model that can be used to inform future national or international monitoring networks.

Future improvements for the network include instrument specific $\mathrm{H}_{2} \mathrm{O}$ corrections for the CRDSs, target tanks as an independent quality control measure, the inclusion of more optical measurements into the network to obtain data at higher frequency data and capture episodic interesting signals, and developing uncertainty algorithms that represent the main sources of error within the data.

Data availability. In situ atmospheric greenhouse gas data from the UK DECC network is available online. Discrete sample and hourly mean data are freely available from EBAS at http://ebas.nilu.no/ for GC-ECD/RGA and CRDS, respectively, for all three UK sites. All MHD data, except CO mole fractions, are available from CDIAC (Prinn et al., 2017).
Competing interests. The authors declare that they have no conflict of interest.

Special issue statement. This article is part of the special issue "Greenhouse gAs Uk and Global Emissions (GAUGE) project (ACP/AMT inter-journal SI)". It is not associated with a conference.

Acknowledgements. We specifically acknowledge the cooperation and efforts of the station operators Gerard Spain and Duncan Brown at Mace Head monitoring station, and Stephen Humphrey and Andy MacDonald at the Tacolneston tall tower station. We also thank the Physics Department, National University of Ireland, Galway, for making the research facilities at Mace Head available. The operation of all stations was funded by the UK Department of Business, Energy and Industrial Strategy (formerly the Department of Energy and Climate Change) through contract TRN1028/06/2015 with additional funding at Mace Head under NASA contract NNX11AF17G through MIT with a sub-award 5710002970 to the UoB.

Edited by: Marc von Hobe

Reviewed by: two anonymous referees

\section{References}

Andrews, A. E., Kofler, J. D., Trudeau, M. E., Williams, J. C., Neff, D. H., Masarie, K. A., Chao, D. Y., Kitzis, D. R., Novelli, P. C., Zhao, C. L., Dlugokencky, E. J., Lang, P. M., Crotwell, M. J., Fischer, M. L., Parker, M. J., Lee, J. T., Baumann, D. D., Desai, A. R., Stanier, C. O., De Wekker, S. F. J., Wolfe, D. E., Munger, J. W., and Tans, P. P.: $\mathrm{CO}_{2}, \mathrm{CO}$, and $\mathrm{CH}_{4}$ measurements from tall towers in the NOAA Earth System Research Laboratory's Global Greenhouse Gas Reference Network: instrumentation, uncertainty analysis, and recommendations for future high-accuracy greenhouse gas monitoring efforts, Atmos. Meas. Tech., 7, 647687, https://doi.org/10.5194/amt-7-647-2014, 2014.

Arnold, T., Mühle, J., Salameh, P. K., Harth, C. M., Ivy, D. J., and Weiss, R. F.: Automated Measurement of Nitrogen Trifluoride in Ambient Air, Anal. Chem., 84, 4798-4804, https://doi.org/10.1021/ac300373e, 2012.

Brailsford, G. W., Stephens, B. B., Gomez, A. J., Riedel, K., Mikaloff Fletcher, S. E., Nichol, S. E., and Manning, M. R.: Long-term continuous atmospheric $\mathrm{CO}_{2}$ measurements at Baring Head, New Zealand, Atmos. Meas. Tech., 5, 3109-3117, https://doi.org/10.5194/amt-5-3109-2012, 2012.

Chen, H., Winderlich, J., Gerbig, C., Hoefer, A., Rella, C. W., Crosson, E. R., Van Pelt, A. D., Steinbach, J., Kolle, O., Beck, V., Daube, B. C., Gottlieb, E. W., Chow, V. Y., Santoni, G. W., and Wofsy, S. C.: High-accuracy continuous airborne measurements of greenhouse gases $\left(\mathrm{CO}_{2}\right.$ and $\left.\mathrm{CH}_{4}\right)$ using the cavity ringdown spectroscopy (CRDS) technique, Atmos. Meas. Tech., 3, 375-386, https://doi.org/10.5194/amt-3-375-2010, 2010.

Crosson, E. R.: A cavity ring-down analyser for measuring atmospheric levels of methane, carbon dioxide, and water vapor, Appl. 
Phys. B, 92, 403-408, https://doi.org/10.1007/s00340-008-3135y, 2008.

Cunnold, D. M., Weiss, R. F., Prinn, R. G., Hartley, D., Simmonds, P. G., Fraser, P. J., Miller, B., Alyea, F. N., and Porter, L.: GAGE/AGAGE measurements indicating reductions in global emissions of CCl3F and CCl2F2 in 1992-1994, J. Geophys. Res., 102, 1259-1269, https://doi.org/10.1029/96JD02973, 1997.

DEFRA: Waste water treatment in the United Kingdom-2012: Implementation of the European Union Urban Waste Water treatment directive 91/271/EEC,PB13811, Department for Environment, Food and Rural Affairs, London, 2012.

Dimmer, C. H., Simmonds, P. G., Nickless, G., and Bassford, M. R.: Biogenic fluxes of halomethanes from Irish peatland ecosystems, Atmos. Environ., 35, 321-330, 2001.

Dlugokencky, E. J., Myers, R. C., Lang, P. M., Masarie, K. A., Crotwell, A. M., Thoning, K. W., Hall, B. D., Elkins, J. W., and Steele, L. P.: Conversion of NOAA atmospheric dry air $\mathrm{CH}_{4}$ mole fractions to a gravimetrically prepared standard scale, J. Geophys. Res, 110, D18306, https://doi.org/10.1029/2005JD006035, 2005.

Dlugokencky, E. J., Nisbet, E. G., Fisher, R., and Lowry, D.: Global atmospheric methane: budget, changes and dangers, Philos. T. R. Soc. S.-A, 369, 2058-2072, https://doi.org/10.1098/rsta.2010.0341, 2011.

Environment Agency: Authorised Landfill Sites, available at: http:// apps.environment-agency.gov.uk/wiyby/37823.aspx (last access: 8 March 2018), 2017.

Ganesan, A. L., Chatterjee, A., Prinn, R. G., Harth, C. M., Salameh, P. K., Manning, A. J., Hall, B. D., Mühle, J., Meredith, L. K., Weiss, R. F., O'Doherty, S., and Young, D.: The variability of methane, nitrous oxide and sulfur hexafluoride in Northeast India, Atmos. Chem. Phys., 13, 10633-10644, https://doi.org/10.5194/acp-13-10633-2013, 2013.

Ganesan, A. L., Manning, A. J., Grant, A., Young, D., Oram, D. E., Sturges, W. T., Moncrieff, J. B., and O'Doherty, S.: Quantifying methane and nitrous oxide emissions from the UK and Ireland using a national-scale monitoring network, Atmos. Chem. Phys., 15, 6393-6406, https://doi.org/10.5194/acp-156393-2015, 2015.

Gerbig, C., Lin, J. C., Wofsy, S. C., Daube, B. C., Andrews, A. E., Stephens, B. B., Bakwin, P. S., and Grainger, C. A.: Toward constraining regional-scale fluxes of $\mathrm{CO}_{2}$ with atmospheric observations over a continent: 1 . Observed spatial variability from airborne platforms J. Geophys. Res., 108, 4756, https://doi.org/10.1029/2002JD003018, 2003.

Gerbig, C., Dolman, A. J., and Heimann, M.: On observational and modelling strategies targeted at regional carbon exchange over continents, Biogeosciences, 6, 1949-1959, https://doi.org/10.5194/bg-6-1949-2009, 2009.

Gloor, M., Bakwin, P., Hurst, D., Lock, L., Draxler, R., and Tans, P.: What is the concentration footprint of a tall tower?, J. Geophys. Res.-Atmos., 106, 17831-17840, https://doi.org/10.1029/2001JD900021, 2001.

Grant, A., Stanley, K. F., Henshaw, S. J., Shallcross, D. E., and O'Doherty, S.: High-frequency urban measurements of molecular hydrogen and carbon monoxide in the United Kingdom, Atmos. Chem. Phys., 10, 4715-4724, https://doi.org/10.5194/acp10-4715-2010, 2010a.
Grant, A., Witham, C. S., Simmonds, P. G., Manning, A. J., and O'Doherty, S.: A 15 year record of high-frequency, in situ measurements of hydrogen at Mace Head, Ireland, Atmos. Chem. Phys., 10, 1203-1214, https://doi.org/10.5194/acp10-1203-2010, 2010b.

GRO: General Register Office for Scotland, available at: http: //www.gro-scotland.gov.uk/ (last access: 9 September 2017), 2013.

Hall, B. D., Dutton, G. S., and Elkins, J. W.: The NOAA nitrous oxide standard scale for atmospheric observations, J. Geophys. Res., 112, D09305, https://doi.org/10.1029/2006JD007954, 2007.

Hall, B. D., Dutton, G. S., Mondeel, D. J., Nance, J. D., Rigby, M., Butler, J. H., Moore, F. L., Hurst, D. F., and Elkins, J. W.: Improving measurements of $\mathrm{SF}_{6}$ for the study of atmospheric transport and emissions, Atmos. Meas. Tech., 4, 2441-2451, https://doi.org/10.5194/amt-4-2441-2011, 2011.

Haszpra, L., Barcza, Z., Bakwin, P. S., Berger, B. W., Davis, K. J., and Weidinger, T.: Measuring system for the long-term monitoring of biosphere/atmosphere exchange of carbon dioxide, J. Geophys. Res, 106, 3057-3069, https://doi.org/10.1029/2000jd900600, 2001.

Hazan, L., Tarniewicz, J., Ramonet, M., Laurent, O., and Abbaris, A.: Automatic processing of atmospheric $\mathrm{CO}_{2}$ and $\mathrm{CH}_{4}$ mole fractions at the ICOS Atmosphere Thematic Centre, Atmos. Meas. Tech., 9, 4719-4736, https://doi.org/10.5194/amt-9-47192016, 2016.

Jennings, S. G., Kleefeld, C., O'Dowd, C. D., Junker, C., Spain, T. G., O Brien, P., Roddy, A. F., and O'Connor, T. C.: Mace Head Atmospheric Research Station-characterization of aerosol radiative parameters, Boreal Environ. Res., 8, 303-314, 2003.

Jones, A. R., Thomson, D. J., Hort, M., and Devenish, B.: The U.K. Met Office's next-generation atmospheric dispersion model, NAME III, in: Air Pollution Modeling and its Application XVII Proceedings of the 27th NATO/CCMS International Technical Meeting on Air Pollution Modelling and its Application, edited by: Borrego, C. and Norman, A.-L., 580-589, 2007,

Keeling, C. D., Bacastow, R. B., Bainbridge, A. E., Ekdahl, C. A., Guenther, P. R., Waterman, L. S., and Chin, J. F. S.: Atmospheric carbon dioxide variations at Mauna Loa Observatory, Hawaii, Tellus, 28, 538-551, https://doi.org/10.1111/j.21533490.1976.tb00701.x, 1976.

Kirschke, S., Bousquet, P., Ciais, P., Saunois, M., Canadell, J. G., Dlugokencky, E. J., Bergamaschi, P., Bergmann, D., Blake, D. R., Bruhwiler, L., Cameron-Smith, P., Castaldi, S., Chevallier, F., Feng, L., Fraser, A., Heimann, M., Hodson, E. L., Houweling, S., Josse, B., Fraser, P. J., Krummel, P. B., Lamarque, J.F., Langenfelds, R. L., Le Quere, C., Naik, V., O’Doherty, S., Palmer, P. I., Pison, I., Plummer, D., Poulter, B., Prinn, R. G., Rigby, M., Ringeval, B., Santini, M., Schmidt, M., Shindell, D. T., Simpson, I. J., Spahni, R., Steele, L. P., Strode, S. A., Sudo, K., Szopa, S., van der Werf, G. R., Voulgarakis, A., van Weele, M., Weiss, R. F., Williams, J. E., and Zeng, G.: Three decades of global methane sources and sinks, Nat. Geosci., 6, 813-823, https://doi.org/10.1038/ngeo1955, 2013.

Kozlova, E. A., Manning, A. C., Kisilyakhov, Y., Seifert, T., and Heimann, M.: Seasonal, synoptic, and diurnal-scale variability of biogeochemical trace gases and $\mathrm{O}_{2}$ from a 300-m tall 
toer in central Siberia, Global Biogeochem. Cy., 22, GB4020, https://doi.org/10.1029/2008GB003209, 2008.

Le Quéré, C., Moriarty, R., Andrew, R. M., Canadell, J. G., Sitch, S., Korsbakken, J. I., Friedlingstein, P., Peters, G. P., Andres, R. J., Boden, T. A., Houghton, R. A., House, J. I., Keeling, R. F., Tans, P., Arneth, A., Bakker, D. C. E., Barbero, L., Bopp, L., Chang, J., Chevallier, F., Chini, L. P., Ciais, P., Fader, M., Feely, R. A., Gkritzalis, T., Harris, I., Hauck, J., Ilyina, T., Jain, A. K., Kato, E., Kitidis, V., Klein Goldewijk, K., Koven, C., Landschützer, P., Lauvset, S. K., Lefèvre, N., Lenton, A., Lima, I. D., Metzl, N., Millero, F., Munro, D. R., Murata, A., Nabel, J. E. M. S., Nakaoka, S., Nojiri, Y., O’Brien, K., Olsen, A., Ono, T., Pérez, F. F., Pfeil, B., Pierrot, D., Poulter, B., Rehder, G., Rödenbeck, C., Saito, S., Schuster, U., Schwinger, J., Séférian, R., Steinhoff, T., Stocker, B. D., Sutton, A. J., Takahashi, T., Tilbrook, B., van der Laan-Luijkx, I. T., van der Werf, G. R., van Heuven, S., Vandemark, D., Viovy, N., Wiltshire, A., Zaehle, S., and Zeng, N.: Global Carbon Budget 2015, Earth Syst. Sci. Data, 7, 349-396, https://doi.org/10.5194/essd-7-349-2015, 2015.

Levin, I., Naegler, T., Heinz, R., Osusko, D., Cuevas, E., Engel, A., Ilmberger, J., Langenfelds, R. L., Neininger, B., Rohden, C. V., Steele, L. P., Weller, R., Worthy, D. E., and Zimov, S. A.: The global $\mathrm{SF}_{6}$ source inferred from long-term high precision atmospheric measurements and its comparison with emission inventories, Atmos. Chem. Phys., 10, 2655-2662, https://doi.org/10.5194/acp-10-2655-2010, 2010.

Luan, T., Fang, S., Yao, B., Wang, H., Dong, F., Shi, Q., Zhou, L., and Zhou, H.: Atmospheric molecular hydrogen $(\mathrm{H} 2)$ at the Shangdianzi regional background station in China, Atmos. Environ., 145, 318-325, https://doi.org/10.1016/j.atmosenv.2016.09.044, 2016.

Manning, A. J., O’Doherty, S., Jones, A. R., Simmonds, P. G., and Derwent, R. G.: Estimating UK methane and nitrous oxide emissions from 1990 to 2007 using an inversion modeling approach, J. Geophys. Res., 116, D02305, 10.1029/2010jd014763, 2011.

Miller, B. R., Weiss, R. F., Salameh, P. K., Tanhua, T., Greally, B. R., Muhle, J., and Simmonds, P. G.: Medusa: A Sample Preconcentration and GC/MS Detector System for in Situ Measurements of Atmospheric Trace Halocarbons, Hydrocarbons, and Sulfur Compounds, Anal. Chem., 80, 1536-1545, 2008.

MREUK: Eye Power Station, available at: http://www.mreuk.com/ eye (last access: 8 March 2018), 2016.

Nevison, C. D., Dlugokencky, E., Dutton, G., Elkins, J. W., Fraser, P., Hall, B., Krummel, P. B., Langenfelds, R. L., O’Doherty, S., Prinn, R. G., Steele, L. P., and Weiss, R. F.: Exploring causes of interannual variability in the seasonal cycles of tropospheric nitrous oxide, Atmos. Chem. Phys., 11, 3713-3730, https://doi.org/10.5194/acp-11-3713-2011, 2011.

ONS: Office for National Statistics, 2011 Census of England and Wales, 2012.

Popa, M. E., Gloor, M., Manning, A. C., Jordan, A., Schultz, U., Haensel, F., Seifert, T., and Heimann, M.: Measurements of greenhouse gases and related tracers at Bialystok tall tower station in Poland, Atmos. Meas. Tech., 3, 407-427, https://doi.org/10.5194/amt-3-407-2010, 2010.

Prinn, R. G., Weiss, R. F., Fraser, P. J., Simmonds, P. G., Cunnold, D. M., Alyea, F. N., O’Doherty, S., Salameh, P., Miller, B. R., Huang, J., Wang, R. H. J., Hartley, D. E., Harth, C., Steele, L. P., Sturrock, G., Midgley, P. M., and McCulloch, A.: A his- tory of chemically and radiatively important gases in air deduced from ALE/GAGE/AGAGE, J. Geophys. Res., 105, 1775117792, https://doi.org/10.1029/2000JD900141, 2000.

Prinn, R. G., Weiss, R. F., Krummel, P. B., O’Doherty, S., Fraser, P. J., Mühle, J., Reimann, S., Vollmer, M. K., Simmonds, P. G., Maione, M., Arduini, J., Lunder, C. R., Schmidbauer, N., Young, D., Wang, H. J., Huang, J., Rigby, M., Harth, C. M., Salameh, P. K., Spain, T. G., Steele, L. P., Arnold, T., Kim, J., Hermansen, O., Derek, N., Mitrevski, B., and Langenfelds, R.: The ALE/GAGE/AGAGE Network (DB1001), Carbon Dioxide Information Analysis Center (CDIAC), Oak Ridge National Laboratory, https://doi.org/10.3334/CDIAC/atg.db1001, 2017.

Rella, C.: Accurate greenhouse gas measurements in humid gas streams using the Picarro G1301 carbon dioxide/methane/water vapor gas analyzer, White paper, Picarro Inc, Sunnyvale, CA, USA, 2010.

Rella, C. W., Chen, H., Andrews, A. E., Filges, A., Gerbig, C., Hatakka, J., Karion, A., Miles, N. L., Richardson, S. J., Steinbacher, M., Sweeney, C., Wastine, B., and Zellweger, C.: High accuracy measurements of dry mole fractions of carbon dioxide and methane in humid air, Atmos. Meas. Tech., 6, 837-860, https://doi.org/10.5194/amt-6-837-2013, 2013.

Satar, E., Berhanu, T. A., Brunner, D., Henne, S., and Leuenberger, M.: Continuous $\mathrm{CO}_{2} / \mathrm{CH}_{4} / \mathrm{CO}$ measurements (2012-2014) at Beromünster tall tower station in Switzerland, Biogeosciences, 13, 2623-2635, https://doi.org/10.5194/bg-13-2623-2016, 2016.

Schmidt, M., Glatzel-Mattheier, H., Sartorius, H., Worthy, D. E., and Levin, I.: Western European $\mathrm{N}_{2} \mathrm{O}$ emissions: A top-down approach based on atmospheric observations, J. Geophys. Res.-Atmos., 106, 5507-5516, https://doi.org/10.1029/2000JD900701, 2001.

Stocker, T. F., Qin, D., Plattner, G. K., Tignor, M., Allen, S. K., Boschung, J., Nauels, A., Xia, Y., Bex, V., and Midgley, P. M.: Climate Change 2013: The Physical Science Basis. Contribution of Working Group I to the Fifth Assessment Report of the Intergovernmental Panel on Climate Change, Cambridge University Press, Cambridge, United Kingdom and New York, NY, USA, 1535, https://doi.org/10.1017/CBO9781107415324, 2013.

Tans, P. P.: Observational strategy for assessing the role of terrestrial ecosystems in the global carbon cycle: scaling down to regional levels, in: Scaling physiological processes: leaf to globe, edited by: Ebleringer, J. R. and Field, C. B., Academic Press, San Diego, California, USA, 179-190, 1993.

Thompson, R. L., Manning, A. C., Gloor, E., Schultz, U., Seifert, T., Hänsel, F., Jordan, A., and Heimann, M.: In-situ measurements of oxygen, carbon monoxide and greenhouse gases from Ochsenkopf tall tower in Germany, Atmos. Meas. Tech., 2, 573591, https://doi.org/10.5194/amt-2-573-2009, 2009.

Tremblay, A., Lambert, M., and Gagnon, L.: Do Hydroelectric Reservoirs Emit Greenhouse Gases?, Environ. Manage., 33, S509-S517, https://doi.org/10.1007/s00267-003-9158-6, 2004.

Vardag, S. N., Hammer, S., O’Doherty, S., Spain, T. G., Wastine, B., Jordan, A., and Levin, I.: Comparisons of continuous atmospheric $\mathrm{CH}_{4}, \mathrm{CO}_{2}$ and $\mathrm{N}_{2} \mathrm{O}$ measurements - results from a travelling instrument campaign at Mace Head, Atmos. Chem. Phys., 14, 8403-8418, https://doi.org/10.5194/acp-148403-2014, 2014.

Verhulst, K. R., Karion, A., Kim, J., Salameh, P. K., Keeling, R. F., Newman, S., Miller, J., Sloop, C., Pongetti, T., Rao, P., Wong, C., 
Hopkins, F. M., Yadav, V., Weiss, R. F., Duren, R. M., and Miller, C. E.: Carbon dioxide and methane measurements from the Los Angeles Megacity Carbon Project - Part 1: calibration, urban enhancements, and uncertainty estimates, Atmos. Chem. Phys., 17, 8313-8341, https://doi.org/10.5194/acp-17-8313-2017, 2017.

Vermeulen, A. T.: CHIOTTO Final Report, ECN energy research Centre of the Netherlands, Petten, the Netherlands, 2007.

Vermeulen, A. T., Hensen, A., Popa, M. E., van den Bulk, W. C. M., and Jongejan, P. A. C.: Greenhouse gas observations from Cabauw Tall Tower (1992-2010), Atmos. Meas. Tech., 4, 617644, https://doi.org/10.5194/amt-4-617-2011, 2011.

Winderlich, J., Chen, H., Gerbig, C., Seifert, T., Kolle, O., Lavric, J. V., Kaiser, C., Höfer, A., and Heimann, M.: Continuous lowmaintenance $\mathrm{CO}_{2} / \mathrm{CH}_{4} / \mathrm{H}_{2} \mathrm{O}$ measurements at the Zotino Tall Tower Observatory (ZOTTO) in Central Siberia, Atmos. Meas. Tech., 3, 1113-1128, https://doi.org/10.5194/amt-3-1113-2010, 2010.
WMO-GAW: 18th WMO/IAEA Meeting on Carbon Dioxide, Other Greenhouse Gases and Related Tracers Measurement Techniques (GGMT-2015), La Jolla, CA, USA, 13-17 September 2015, WMO, Geneva, Switzerland, 2016.

Yver Kwok, C., Laurent, O., Guemri, A., Philippon, C., Wastine, B., Rella, C. W., Vuillemin, C., Truong, F., Delmotte, M., Kazan, V., Darding, M., Lebègue, B., Kaiser, C., XuerefRémy, I., and Ramonet, M.: Comprehensive laboratory and field testing of cavity ring-down spectroscopy analyzers measuring $\mathrm{H}_{2} \mathrm{O}, \mathrm{CO}_{2}, \mathrm{CH}_{4}$ and CO, Atmos. Meas. Tech., 8, 3867-3892, https://doi.org/10.5194/amt-8-3867-2015, 2015.

Zhao, C. L. and Tans, P. P.: Estimating uncertainty of the WMO mole fraction scale for carbon dioxide in air, J. Geophys. Res, 111, D08S09, https://doi.org/10.1029/2005JD006003, 2006. 